\title{
Foliar Applications of Biostimulants Promote Growth, Yield and Fruit Quality of Strawberry Plants Grown under Nutrient Limitation
}

\author{
Sebastian Soppelsa ${ }^{1,2}$, Markus Kelderer ${ }^{2}$, Claudio Casera ${ }^{2}$, Michele Bassi ${ }^{2}$, \\ Peter Robatscher ${ }^{2}\left(\mathbb{D}\right.$, Aldo Matteazzi ${ }^{2}$ and Carlo Andreotti ${ }^{1, * \mathbb{D}}$ \\ 1 Faculty of Science and Technology, Free University of Bozen-Bolzano, Piazza Università, \\ 5-39100 Bozen-Bolzano, Italy \\ 2 Laimburg Research Centre, Laimburg 6, 39051 Pfatten-Vadena, Italy \\ * Correspondence: carlo.andreotti@unibz.it
}

Received: 11 July 2019; Accepted: 22 August 2019; Published: 26 August 2019

\begin{abstract}
Biostimulants have been found effective in enhancing plant resistance toward stressful conditions. The aim of the present study was to evaluate the efficacy of selected biostimulants to overcome the negative effects of nutrient limitation on the growth performances and on the fruit quality of soilless cultivated strawberry plants. The condition of nutrient limitation was imposed by supplying the plants with only a single fertilization at transplantation and by excluding any further nutrient supply for the entire duration of the experiment (three months, from May to July). Strawberry plants were treated seven times during the period from preflowering up to berry maturation with different classes of biostimulants (humic acids, alfalfa hydrolysate, macroseaweed extract and microalga hydrolysate, amino acids alone or in combination with zinc, B-group vitamins, chitosan, and a commercial product containing silicon) at commercial dosages. The use of alfalfa hydrolysate, vitamins, chitosan, and silicon was able to promote biomass accumulation in roots (four to seven folds) and fruits $(+20 \%)$ of treated plants, whereas the total leaf area increased by $15 \%-30 \%$. Nutrient concentrations in leaves and roots showed variations for microelements (e.g., $\mathrm{Fe}, \mathrm{B}$, $\mathrm{Zn}$, and $\mathrm{Si}$ ) in response to biostimulant applications, whereas no significant differences were observed for macronutrient contents among treatments. Final berry yield was found around $20 \%$ higher in chitosan- and silicon-treated plants. Chitosan treatment significantly increased pulp firmness (by $20 \%$ ), while a high nutritional value (e.g., phenolic compounds concentration) was observed in alfalfa- and seaweed-treated fruits $(+18 \%-20 \%$ as compared to control). The overall outcomes of the present experiment show that selected biostimulants can be considered as a valid agronomic tool able to contrast the negative consequence of growing crops under insufficient nutritional conditions.
\end{abstract}

Keywords: soilless conditions; abiotic stress; alfalfa hydrolysate; chitosan; zinc; ascorbic acid; Fragaria $x$ ananassa

\section{Introduction}

The nutritional status of strawberry plants is of major relevance for the achievement of the expected levels of productivity and overall fruit quality [1]. Growth, yield, and quality parameters were found to be positively correlated with the rate of mineral nutrients (macro and micro) used during the strawberry production cycle [1-3]. The current world strawberry production is often conducted under covered systems (greenhouses and plastic tunnels) and in combination with soilless technologies [4]. Soilless production systems require a particularly fine control of nutrient supply, but this control is difficult to be achieved especially when the use of mineral fertilizers is banned (i.e., in organic farming). 
Under such conditions, nutrient deficiencies/imbalances often become a severe limiting factor for the overall economic sustainability of the cultivation $[5,6]$.

With the aim to help both organic and integrated growers to overcome the problem of the insufficient nutritional status of soilless cultivated crops, different technical solutions are currently available on the market of fertilizer products, including the vast group of biostimulant compounds. These compounds were recently considered in the new EU regulation of fertilizer products and defined as products able to improve one or more of the following characteristics: (i) nutrient use efficiency; (ii) tolerance toward abiotic stresses; (iii) quality traits and (iv) the availability of confined nutrients in soil or the rhizosphere [7].

During the last few years, the international scientific literature has largely documented the beneficial effects of the use of biostimulants on several different crops. As for the use of biostimulant to contrast abiotic stresses, Goñi et al. [8] and Di Stasio et al. [9] recently reported the use of seaweed extracts from Ascophyllum nodosum to enhance the tolerance of tomato plants to drought and salinity stress, respectively. This positive effect was observed also with other biostimulants, such as protein hydrolysate on lettuce [10], chitosan on white clover [11], and silicon on tomato [12]. Regarding the stress caused by nutrient deficiency, biostimulants can contribute to soil nutrient availability, uptake, and assimilation of nutrients to the plants [13]. Mechanisms by which biostimulants affect nutrient uptake are generally related to an improvement of physicochemical properties of soil, nutrient solubility, root morphology, and root colonization by arbuscular mycorrhizal fungi $[13,14]$. Mattner et al. [15] found an increased root length and density in strawberry plants treated with seaweed extracts (Duvillaea potatorum and A. nodosum), which implies a more efficient use of nutrients by the crop. Extracts from other seaweed species (e.g., Ecklonia maxima and Kappaphycus alvarezii) also increased the uptake of several macro- and micronutrients, leading to a higher biomass accumulation and final yield in lettuce, soybean, and zucchini squash [16-18]. Spinelli et al. [19] observed the efficacy of seaweed extract in increasing root growth and enhancing tolerance to iron deficiency on strawberry plants, demonstrating that $A$. nodosum might be a valid substitute of Fe-chelate compounds (e.g., sequestrene). In addition to seaweed extracts, other biostimulant products based on amino acids (such as arginine, glycine, histidine, and phenylalanine) were also found to be able to reduce the negative effects of iron-induced chlorosis and the incidence of physiological disorders in horticultural products (tomato and apple) $[20,21]$.

Biostimulants were also found to be effective in promoting yield in several vegetable and fruit species, while differently modulating the nutritional and functional properties of their edible products. Foliar applications of different biostimulants (protein hydrolysate, seaweed, and plant extracts) were all effective in increasing the yield of greenhouse tomato but showed different modulating effects on final fruit quality (e.g., protein hydrolysate-treated fruits showed a higher lycopene concentration, whereas treatments with plant extracts reduced the level of undesirable components such as nitrates) [22]. As concerns the fruit crops, the application of seaweed extracts increased the total soluble solids and organic acids content of mango fruits [23], whereas the use of chitosan and humic acids enhanced the strawberry fruit average size and marketability [24,25]. Also well-established is the induction effect of several biostimulants on the phenolic and flavonoid metabolism in horticultural crops. Treatments with $A$. nodosum induced a higher accumulation of total anthocyanins in strawberry fruits [26], whereas the application of plant and seaweed-based extracts increased total phenolics accumulation in spinach leaves $[27,28]$. Chitosan and alginate applications promoted the accumulation of anthocyanin and phenolic acids such as 3-O-glucosyl-resveratrol in Vitis vinifera [29]. Portu et al. [30] and El-Sayed [31] showed that the application of amino acids (e.g., phenylalanine) can enhance the content of anthocyanins, flavonols, and the total phenols in table grape. These biostimulants resulted in being able to be active on the phenylpropanoid pathway of the treated plants, as demonstrated by the enhanced expression of constitutive genes such as PAL, CHS, and CHI [32-37].

The purpose of this study was to understand if the use of selected biostimulant products could be considered to contrast the negative effects of nutrient limitation in soilless cultivated strawberry. With 
this aim, repeated preharvest applications of biostimulant compounds were performed and the effects on the growth and fruit yield measured. Moreover, changes in strawberry quality and nutritional value (total phenolic and anthocyanin content, antioxidant potential) were evaluated. Some of the selected substances were tested for the first time on strawberry plants and, to the best of our knowledge, this was the first study where the efficacy of several biostimulants was evaluated simultaneously during the same growing cycle.

\section{Materials and Methods}

\subsection{Experimental Site and Biostimulant Applications}

The trial was carried out in a greenhouse located at the Laimburg Research Centre, municipality of Vadena/Pfatten ( $46^{\circ} 22^{\prime} \mathrm{N}$; $11^{\circ} 17^{\prime} \mathrm{E} ; 237 \mathrm{~m}$ a.s.l.) in Alto-Adige/South Tyrol, Italy, during the period April-July 2016. Climatic conditions inside the greenhouse (temperature and humidity) were monitored and are reported in Figure 1.

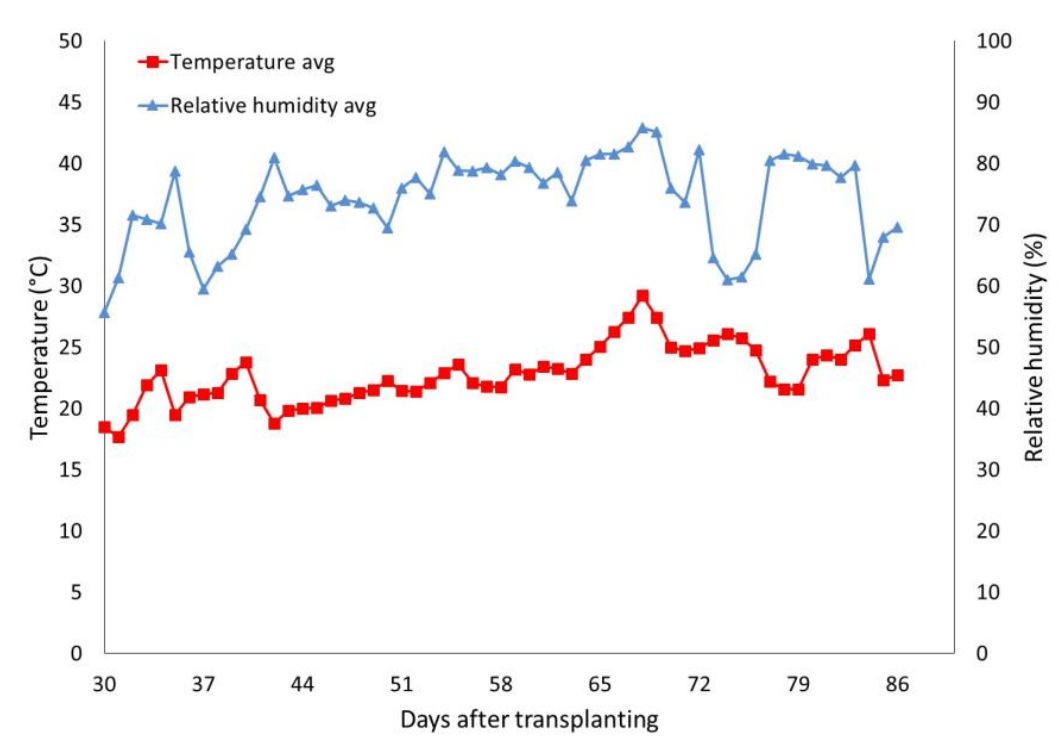

Figure 1. Climatic conditions (average daily temperature and relative humidity) inside the greenhouse during the evaluation period.

A total of 176 cold stored strawberry tray plants (Fragaria $\times$ ananassa Duch.) $\mathrm{cv}$. Elsanta (the most commonly chosen cultivar for protected and open field cultivation in the area), very uniform in size and general conditions (Figure S1, Supplementary Material), were transplanted (4 plants per pot) on the 21st of April 2016 into rectangular plastic pots having the following size: $48 \times 23 \times 13 \mathrm{~cm}$. A mixture of white peat and natural clay was used as growth medium. A week after the transplantation, plants were fertigated as used commercially for strawberry under greenhouse conditions with a starter fertilizer NPK (24-10-10 and microelements; Peters Excel, Scotts Company, Italy) at a rate of $1 \mathrm{~g} \mathrm{~L}^{-1}$ (EC $1.1 \mathrm{mS} \mathrm{cm}^{-1} ; 0.15 \mathrm{~L}$ of solution plant ${ }^{-1}$ ). Details on the substrate and on the nutrient solution composition are shown in Table 1. The plant material was characterized at the beginning of the experiment (at transplantation) by assessing the dry weight of the different organs (Table 2). For this purpose, four strawberry plants out of the initial group of plants were randomly sampled, washed, and divided into roots, crowns, and leaves. The plant organs were then put in an oven (ED 56, Binder $\mathrm{GmbH}$, Tuttlingen, Germany) at $65{ }^{\circ} \mathrm{C}$ until they reached a stable weight and the dry mass recorded (g dry weight (DW) plant ${ }^{-1}$ ). Moreover, mineral element concentration in leaves and roots was determined as described in Section 2.5 (Table 2). All plants were uniformly irrigated until runoff at two-day intervals using a watering can. During the growing cycle, no chemical pesticides were used, and no further fertilization with mineral nutrients was applied to plants for the whole experiment 
duration. Starting from the 20th of May (at preflowering stage, 30 DAT-days after transplanting), plants were foliar treated at weekly intervals with the biostimulant products. Seven applications were performed, in total using 10 different biostimulants. Details on the names, abbreviations and physicochemical characteristics of the utilized biostimulants are reported in Table 3. The applied concentrations were those reported in the label for commercial products, whereas those treatments still at prototype stage were applied according the information found in literature for similar compounds. The mechanism by which foliar applied biostimulants penetrate the leaf surface was not investigated in the present research, even though other studies conducted on similar products evidenced that the penetration occurs mainly through the cuticular layer and the stoma [38]. The penetration of these substances into leaves is a passive process and is influenced by several factors, including the concentration and the chemical nature of the applied molecules, the morphology of the leaf cuticle, and the degree of the stomatal opening [39]. Control plants were sprayed only with water. All the plants were sprayed until the runoff point using a hand sprayer ( $50 \mathrm{~mL}$ per plant). Pollination was performed with a brush by taking the pollen from the flower's own anthers. The experiment setup was organized as a completely randomized design with 4 replicates composed by 4 plants per replicate (i.e., 16 plants per treatment and 176 plants in total).

Table 1. Composition of the substrate and of the nutrient solution used for the experiment.

\begin{tabular}{|c|c|c|c|}
\hline \multicolumn{2}{|c|}{ Physico-Chemical Composition of Substrate } & \multicolumn{2}{|c|}{ Composition of the Nutrient Solution Used at Transplant } \\
\hline $\mathrm{pH}$ & 5.1 & $\mathrm{~N}\left(\mathrm{mg} \mathrm{L}^{-1}\right)$ & 240 \\
\hline Dry matter (\%) & 42.6 & $\mathrm{P}_{2} \mathrm{O}_{5}\left(\mathrm{mg} \mathrm{L}^{-1}\right)$ & 100 \\
\hline Humidity (\%) & 57.4 & $\mathrm{~K}_{2} \mathrm{O}\left(\mathrm{mg} \mathrm{L}^{-1}\right)$ & 100 \\
\hline Soluble salts $\left(\mathrm{g} \mathrm{L}^{-1}\right)$ & 2.0 & $\mathrm{~B}\left(\mathrm{mg} \mathrm{L}^{-1}\right)$ & 0.2 \\
\hline $\mathrm{NO}_{3}\left(\mathrm{mg} \mathrm{L}^{-1}\right)$ & 3.3 & $\mathrm{Cu}\left(\mathrm{mg} \mathrm{L}^{-1}\right)$ & 0.1 \\
\hline $\mathrm{NH}_{4}\left(\mathrm{mg} \mathrm{L}^{-1}\right)$ & 462.7 & $\mathrm{Fe}\left(\mathrm{mg} \mathrm{L}^{-1}\right)$ & 1.2 \\
\hline $\mathrm{P}_{2} \mathrm{O}_{5}\left(\mathrm{mg} \mathrm{L}^{-1}\right)$ & 37.0 & $\operatorname{Mn}\left(\mathrm{mg} \mathrm{L}^{-1}\right)$ & 0.5 \\
\hline $\mathrm{K}_{2} \mathrm{O}\left(\mathrm{mg} \mathrm{L}^{-1}\right)$ & 245.0 & $\operatorname{Mo}\left(\mathrm{mg} \mathrm{L}^{-1}\right)$ & 0.1 \\
\hline $\mathrm{Mg}\left(\mathrm{mg} \mathrm{L}^{-1}\right)$ & 121.0 & $\mathrm{Zn}\left(\mathrm{mg} \mathrm{L}^{-1}\right)$ & 0.3 \\
\hline $\mathrm{Na}\left(\mathrm{mg} \mathrm{L}^{-1}\right)$ & 13.0 & & \\
\hline $\mathrm{B}\left(\mathrm{mg} \mathrm{L}^{-1}\right)$ & 0.26 & & \\
\hline $\mathrm{Fe}\left(\mathrm{mg} \mathrm{L}^{-1}\right)$ & 63.0 & & \\
\hline $\operatorname{Mn}\left(\mathrm{mg} \mathrm{L}^{-1}\right)$ & 10.2 & & \\
\hline $\mathrm{Cu}\left(\mathrm{mg} \mathrm{L}^{-1}\right)$ & 1.2 & & \\
\hline $\mathrm{Zn}\left(\mathrm{mg} \mathrm{L}^{-1}\right)$ & 2.1 & & \\
\hline
\end{tabular}

Table 2. Characterization of the cold stored strawberry plants at the transplanting: dry weight of the organs and mineral element concentrations in leaves and roots.

\begin{tabular}{|c|c|c|c|c|}
\hline \multicolumn{2}{|c|}{ Dry Weight of Plant Organs (g DW ${ }^{a}$ plant $^{-1}$ ) } & \multirow{2}{*}{$\begin{array}{c}\text { Mineral Element } \\
\text { Concentration }\end{array}$} & \multirow{2}{*}{$\begin{array}{c}\text { Leaves } \\
3.90 \pm 0.28\end{array}$} & \multirow{2}{*}{$\begin{array}{c}\text { Roots } \\
2.65 \pm 0.19\end{array}$} \\
\hline Leaves & $2.07 \pm 0.31$ & & & \\
\hline Crown & $0.71 \pm 0.23$ & $\mathrm{P}(\%)$ & $0.55 \pm 0.10$ & $0.43 \pm 0.07$ \\
\hline Roots & $2.17 \pm 0.58$ & $\mathrm{~K}(\%)$ & $3.14 \pm 0.20$ & $0.76 \pm 0.16$ \\
\hline \multirow[t]{10}{*}{ Total weight } & $4.95 \pm 0.97$ & $\mathrm{Ca}(\%)$ & $1.39 \pm 0.20$ & $1.33 \pm 0.34$ \\
\hline & & $\operatorname{Mg}(\%)$ & $0.42 \pm 0.03$ & $0.32 \pm 0.06$ \\
\hline & & $\mathrm{S}(\%)$ & $0.52 \pm 0.26$ & $0.42 \pm 0.13$ \\
\hline & & $\mathrm{B}\left(\mathrm{mg} \mathrm{kg}^{-1}\right)$ & $35.58 \pm 13.20$ & $22.93 \pm 1.66$ \\
\hline & & $\mathrm{Cu}\left(\mathrm{mg} \mathrm{kg}^{-1}\right)$ & $19.98 \pm 9.67$ & $115.13 \pm 65.82$ \\
\hline & & $\mathrm{Fe}\left(\mathrm{mg} \mathrm{kg}^{-1}\right)$ & $74.68 \pm 32.96$ & $149.83 \pm 40.22$ \\
\hline & & $\operatorname{Mn}\left(\mathrm{mg} \mathrm{kg}^{-1}\right)$ & $168.35 \pm 5.84$ & $61.80 \pm 23.66$ \\
\hline & & $\mathrm{Zn}\left(\mathrm{mg} \mathrm{kg}^{-1}\right)$ & $33.35 \pm 5.32$ & $85.68 \pm 40.17$ \\
\hline & & $\mathrm{Na}\left(\mathrm{mg} \mathrm{kg}^{-1}\right)$ & $163.59 \pm 91.87$ & $299.73 \pm 100.71$ \\
\hline & & $\mathrm{Si}\left(\mathrm{mg} \mathrm{kg}^{-1}\right)$ & $382.35 \pm 61.93$ & $181.83 \pm 32.92$ \\
\hline
\end{tabular}

${ }^{a}$ DW: dry weight. 
Table 3. Biostimulant characterization, properties, and concentration applied for the experiment.

\begin{tabular}{|c|c|c|c|c|c|c|c|c|c|c|c|c|c|}
\hline Treatment & Active Ingredients & $\begin{array}{c}\text { Moisture } \\
(\%)\end{array}$ & Ash (\%) & $\begin{array}{l}\text { Density } \\
\left(\mathrm{kg} \mathrm{dm}^{-3}\right)\end{array}$ & $\begin{array}{c}\text { Organic } \\
\text { Matter } \\
(\%)\end{array}$ & $\mathrm{pH}$ & $\begin{array}{l}\text { Electrical } \\
\text { Conductivity } \\
\left(\mathrm{dS} \mathrm{m}^{-1}\right)\end{array}$ & $\begin{array}{c}\text { Total } \\
\text { Organic C } \\
\left(\% w^{-1}\right)\end{array}$ & $\begin{array}{c}\text { Total } \\
\text { Organic } N \\
\left(\% w^{-1}\right)\end{array}$ & $\begin{array}{l}\text { Free Amino } \\
\text { Acids } \\
\left(\% \mathbf{w}^{-1}\right)\end{array}$ & $\begin{array}{l}\text { Total Amino } \\
\text { Acids } \\
\left(\% w^{-1}\right)\end{array}$ & $\begin{array}{c}\text { Other } \\
\text { Characteristics }\end{array}$ & Concentration \\
\hline $\mathrm{CON}$ & Water & & & & & & & & & & & & \\
\hline HAL & Humic acids & - & - & 1.1 & - & 9.2 & 1.2 & 7.5 & 0.1 & - & - & - & $1.0 \mathrm{~g} \mathrm{~L}^{-1}$ \\
\hline $\mathrm{APH}$ & $\begin{array}{l}\text { Alfalfa protein } \\
\text { hydrolysate }\end{array}$ & 70.0 & 7.0 & 1.2 & 23.0 & 5.5 & 1.6 & - & - & 1.5 & 5.1 & - & $3.0 \mathrm{~g} \mathrm{~L}^{-1}$ \\
\hline SEA & $\begin{array}{c}\text { Macroseaweed } \\
\text { extract }\end{array}$ & 84.0 & 1.5 & 1.0 & 14.5 & 4.5 & 0.4 & 3 & $\leq 0.1$ & - & - & $\begin{array}{l}\text { From } A \text {. } \\
\text { nodosum }\end{array}$ & $4.0 \mathrm{~g} \mathrm{~L}^{-1}$ \\
\hline SPI & $\begin{array}{l}\text { Microalga } \\
\text { hydrolysate }\end{array}$ & - & - & 1.2 & - & 5.5 & 1.5 & 16.8 & 3.9 & 6.5 & - & $\begin{array}{c}\text { From Spirulina } \\
\text { spp ( } 37 \% \text { hydrol. } \\
\text { degree })\end{array}$ & $4.0 \mathrm{~g} \mathrm{~L}^{-1}$ \\
\hline MAA & Mix of amino acids & 45.0 & 5.0 & 1.2 & 50.0 & 5.5 & 0.8 & 24.5 & 9 & 1.5 & 55.0 & - & $3.0 \mathrm{~g} \mathrm{~L}^{-1}$ \\
\hline PHE & $\begin{array}{l}\text { MAA combined with } \\
\text { pure phenylalanine }\end{array}$ & 55.0 & 5.0 & 1.2 & 40.0 & 5.5 & - & 19.6 & 7.2 & 1.8 & 45.0 & $\begin{array}{c}\text { Phenylalanine } \\
(1 \%)\end{array}$ & $3.0 \mathrm{~g} \mathrm{~L}^{-1}$ \\
\hline ZIN & $\begin{array}{l}\text { MAA combined with } \\
\text { zinc }\end{array}$ & 55.0 & 7.0 & 1.2 & 38.0 & 5.5 & - & 19.6 & 7.2 & 0.8 & 44.0 & Zn $(2 \%)$ & $3.0 \mathrm{~g} \mathrm{~L}^{-1}$ \\
\hline VIT & $\begin{array}{l}\text { B-group vitamins } \\
\text { (Sigma-Aldrich, } \\
\text { USA) }\end{array}$ & - & - & - & - & - & - & - & - & - & - & $\begin{array}{c}\text { B1-thiamine } \\
(33.3 \%), \\
\text { B2-riboflavin } \\
(33.3 \%), \\
\text { B6-pyridoxine } \\
(33.3 \%)\end{array}$ & $1.0 \mathrm{~g} \mathrm{~L}^{-1}$ \\
\hline $\mathrm{CHI}$ & $\begin{array}{c}\text { Chitosan-ChitoPlant } \\
\text { Solution }{ }^{\circledR} \text { (Agritalia, } \\
\text { Italy) }\end{array}$ & 98.3 & 0.01 & - & 1.7 & 5.2 & - & - & - & - & - & - & $10 \mathrm{~mL} \mathrm{~L}^{-1}$ \\
\hline SIL & $\begin{array}{c}\text { Siliforce }^{\circledR} \text { (ILSA } \\
\text { S.p.A., Italy) }\end{array}$ & - & - & 1.2 & - & 2.0 & - & - & - & - & - & $\begin{array}{c}\mathrm{Si}\left(8 \mathrm{~g} \mathrm{~kg}^{-1}\right), \mathrm{Zn} \\
(1.8 \%), \mathrm{Mo} \\
(0.2 \%)\end{array}$ & $0.3 \mathrm{~mL} \mathrm{~L}^{-1}$ \\
\hline
\end{tabular}




\subsection{Vegetative Growth and Leaf Gas Exchanges}

Plant growth dynamic as affected by biostimulant applications was determined every two weeks from preflowering (about $30 \mathrm{DAT}$ ) to the end of harvest (about $90 \mathrm{DAT}$ ) by measuring the area of two young trifoliate leaves per strawberry plant with a Li-Cor 3000 Leaf Area Meter (Li-Cor Inc., Lincoln, NE, USA). Biomass accumulation in different plant organs was calculated by subtracting the initial dry weight measured at transplanting stage (0 DAT, Table 2$)$ from the final dry weight reached at the end of the growth cycle $(90 \mathrm{DAT})$. The dry weight of the different plant organs at the end of production cycle was determined on four plants per each treatment as previously described in Section 2.1. Measurements included the determination of the final dry matter of organs that were already present at transplanting (roots, crown and leaves) as well as the weight of the newly formed organs (shoots, stolons, and fruits).

The leaf chlorophyll content was indirectly determined with a SPAD-502 Chlorophyll Meter (Konica Minolta, Tokyo, Japan) at biweekly intervals on two randomly selected trifoliate leaves per plant. Moreover, after the plants had received four applications of all the treatments, the net assimilation $\left(\mathrm{A}, \mu \mathrm{mol} \mathrm{m} \mathrm{m}^{-2} \mathrm{~s}^{-1}\right)$ and transpiration $\left(\mathrm{E}, \mathrm{mmol} \mathrm{m} \mathrm{m}^{-2} \mathrm{~s}^{-1}\right)$ rates of leaves were evaluated using a portable gas exchange analyzer (LCpro ADC, Hoddesdon Bioscientific, Ltd, UK). The gas exchange evaluations were conducted immediately before the fifth application of biostimulants (at 57 DAT), and 24 and $48 \mathrm{~h}$ after the application. Measurements were performed on a young, fully expanded single leaf of four randomly selected plants per treatment and were taken under saturating light conditions $(1.800 \mu \mathrm{mol}$ photons $\left.\mathrm{m}^{-2} \mathrm{~s}^{-1}\right)$, around midday (11:00-13:00 h), using a broad leaf gas chamber with a window size of $6.25 \mathrm{~cm}^{2}$ and a flow rate of $400 \mathrm{~mL} \mathrm{~min}^{-1}$.

\subsection{Yield and Fruit Quality}

Ripe strawberry fruits (fully red color) were harvested every three days during the period from approximately 60 to 80 DAT. Harvested berries were counted and weighted with a digital scale in the laboratory. The cumulated yield per plant was determined by adding the weight of all the strawberries collected from the same plant during the harvesting period. Fruit quality was assessed on four strawberries per plant sampled at an intermediate pick during the harvesting period. Flesh firmness $\left(\mathrm{kg} \mathrm{cm}^{-2}\right)$ was measured with a penetrometer equipped with a $6 \mathrm{~mm}$ diameter cap. The total soluble solids ( ${ }^{\circ}$ Brix) was determined with a portable refractometer (PAL-1, ATAGO, Tokyo, Japan), whereas the titratable acidity ( $\mathrm{g} \mathrm{L}^{-1}$ of citric acid) was measured with a titrator (TitroLine easy, SCHOTT, Mainz, Germany) by titrating strawberry pulp to $\mathrm{pH} 8.2$ using $0.1 \mathrm{M} \mathrm{NaOH}$. The external fruit color was assessed with a colorimeter (Minolta, model CR-400, Tokyo, Japan) by measuring the same four fruits at three different positions around the equatorial side of each fruit. The colorimetric coordinates $\left(L^{*}, a^{*}, b^{*}\right)$ were used to calculated the chroma and hue angle values with the formulas (1) and (2), respectively [40].

$$
\begin{aligned}
& C^{*}=\left(a^{* 2}+b^{* 2}\right)^{1 / 2} \\
& h^{\circ}=\arctan \left(b^{*} / a^{*}\right)
\end{aligned}
$$

\subsection{Biochemical Analysis of Strawberry Fruits}

\subsubsection{Sample Preparation and Extraction Procedure}

Around $20 \mathrm{~g}$ of strawberry fruits per replicate was randomly collected at red mature stage and immediately frozen in liquid nitrogen and stored at $-80^{\circ} \mathrm{C}$. The extraction was conducted using $25 \mathrm{mg}$ of lyophilized sample, which was homogenized and extracted in $1.8 \mathrm{~mL}$ of extraction solution $(80 \%$ methanol acidified with $\mathrm{H}_{3} \mathrm{PO}_{4}, \mathrm{pH} 1.0$ ) and in $30 \mu \mathrm{L}$ of $0.1 \mathrm{M} \mathrm{NaF}$ solution for $15 \mathrm{~min}$ at $5^{\circ} \mathrm{C}$. The extract was then filtered with PTFE filters $(0.45 \mathrm{~mm}$, Thermo Fisher Scientific), and the filtrate was stored at $-80^{\circ} \mathrm{C}$ until analysis. The extraction procedure specific for ascorbic acid analysis is described in Section 2.4.5. 


\subsubsection{Total Polyphenols Content (TPC)}

Total phenolic content determination was performed on strawberry fruit extracts using the Folin-Ciocalteu assay following the methodology described in Meyers et al. [41] with some modifications. A total of $60 \mu \mathrm{L}$ of the sample extract was diluted with $250 \mu \mathrm{L}$ of deionized water. Then, $60 \mu \mathrm{L}$ of Folin-Ciocalteu reagents was added, and the mixture was allowed to react in the dark for $6 \mathrm{~min}$ at $20^{\circ} \mathrm{C}$ in agitation at $1500 \mathrm{rpm}$ in the Thermomixer. A total of $630 \mu \mathrm{L}$ of $\mathrm{Na}_{2} \mathrm{CO}_{3}(7.5 \% \mathrm{w} / \mathrm{v})$ was added and incubated for $90 \mathrm{~min}$ at $20^{\circ} \mathrm{C}$ always in the dark and under agitation at $1500 \mathrm{rpm}$. The total polyphenol content was determined at $740 \mathrm{~nm}$ using a spectrophotometer Cary $60 \mathrm{UV}-\mathrm{Vis}$ (Agilent Technologies, Santa Clara, CA, USA). Gallic acid standard solutions were used to calibrate the method (range 5-500 $\mathrm{mg} \mathrm{L}^{-1}, r^{2}>0.999$ ). The content of total polyphenols in each strawberry fruit extract was calculated and expressed as $\mathrm{mg}$ of gallic acid equivalents (GAE) per $100 \mathrm{~g}$ of dry weight (mg GAE $\left.100 \mathrm{~g}^{-1} \mathrm{DW}\right)$.

\subsubsection{Determination of Total Anthocyanin Content (TAC)}

Total anthocyanin content in strawberry extracts was determined according to Lee et al. [42] using the spectrophotometric $\mathrm{pH}$ differential method. Two dilutions of the same sample were prepared by adding $200 \mu \mathrm{L}$ of extract to $800 \mu \mathrm{L}$ of potassium chloride $(0.25 \mathrm{M}, \mathrm{pH} 1)$ and to $800 \mu \mathrm{L}$ of sodium acetate $(0.4 \mathrm{M}, \mathrm{pH} 4.5)$, respectively. Absorbance was measured with a Cary $60 \mathrm{UV}-\mathrm{Vis}$ spectrophotometer at 520 and $700 \mathrm{~nm}$ at $\mathrm{pH} 1$ and 4.5, where $\mathrm{A}=(\mathrm{A} 520-\mathrm{A} 700) \mathrm{pH} 1-(\mathrm{A} 520-\mathrm{A} 700) \mathrm{pH} 4.5$. Total anthocyanin content was calculated using the Lambert-Beer law $\left(\varepsilon=26900 \mathrm{~L} \mathrm{~mol}^{-1} \mathrm{~cm}, \mathrm{MW}=449.2 \mathrm{~g} \mathrm{~mol}^{-1}\right)$ as mg cyanidin 3-glucoside equivalents (CGE) per $100 \mathrm{~g}$ of dry weight (mg CGE $100 \mathrm{~g}^{-1} \mathrm{DW}$ ).

\subsubsection{Antioxidant Activity (ABTS)}

Radical scavenging activity of the strawberry extracts was determined as described by Re et al. [43] with some modifications. ABTS was dissolved in water to a $7 \mathrm{mM}$ concentration; the ABTS radical was obtained from reaction of ABTS stock solution with $2.45 \mathrm{mM}$ potassium persulfate and allowing the mixture to stand in the dark at $4{ }^{\circ} \mathrm{C}$ for $16 \mathrm{~h}$ before use. The ABTS radical solution was diluted with deionized water to reach absorbance of $0.700 \pm 0.02$ at $734 \mathrm{~nm}$. A total of $30 \mu \mathrm{L}$ of each sample extract was added to $1.97 \mathrm{~mL}$ of diluted ABTS solution. The absorbance was measured at $734 \mathrm{~nm}$ on the Cary $60 \mathrm{UV}-\mathrm{Vis}$ spectrophotometer after $10 \mathrm{~min}$ in dark conditions. For each sample, the percentage of inhibition after $10 \mathrm{~min}$ of reaction was measured, and the concentration of sample (Trolox equivalent antioxidant capacity, TEAC) was calculated using the external calibration curve of the Trolox standard (Trolox, range 15.6-500 $\mathrm{mg} \mathrm{L}^{-1}, r^{2}>0.999$ ). The results were expressed as milligrams Trolox equivalents per $100 \mathrm{~g}$ of dry weight (mg Trolox $\left.100 \mathrm{~g}^{-1} \mathrm{DW}\right)$.

\subsubsection{Ascorbic Acid Quantification}

The analytical method for the ascorbic acid was based on Bassi et al. [44]. A total of $50 \mathrm{mg}$ of freeze-dried sample was extracted using $1 \mathrm{~mL}$ of the extraction solution $\left(700 \mu \mathrm{L}\right.$ deionized $\mathrm{H}_{2} \mathrm{O}$ containing $8 \%(v / v)$ acetic acid and 3\% $(w / v)$ metaphosphoric acid added with $300 \mu \mathrm{L}$ of methanol) [45], mixed at $3200 \mathrm{rpm}$ for about $20 \mathrm{~s}$ at room temperature and filtered through a $0.20 \mu \mathrm{m}$ PTFE filter. An HPLC Agilent 1260 Infinity system (Santa Clara, CA, USA) with a diode array (1260 DAD VL) detector, controlled through the software Agilent ChemStation ${ }^{\mathrm{TM}}$ (ver. C.01.03) (Agilent, Santa Clara, CA, USA), was used for the analysis of the ascorbic acid. The separation of the analyte was carried out at $25^{\circ} \mathrm{C}$ using a Kinetex $5 \mu \mathrm{C} 18100 \AA$ column $(150 \mathrm{~mm} \times 4.6 \mathrm{~mm}, 5 \mu \mathrm{m}$ particle size; Phenomenex, Torrance, CA, USA) equipped with a precolumn ( $4.6 \mathrm{~mm}$; Security Card, Phenomenex, Torrance, CA, USA). Detection wavelength was $260 \mathrm{~nm}$. The mobile phases used were $5 \mathrm{mM} \mathrm{KH}_{2} \mathrm{PO}_{4}, \mathrm{pH} 4.8$ (solvent A), and methanol (solvent $\mathrm{B}$ ). The analytical gradient was as follows: $0 \mathrm{~min}, 100 \% \mathrm{~A} ; 2.5 \mathrm{~min}$, $100 \% \mathrm{~A} ; 6 \mathrm{~min}, 80 \% \mathrm{~A} ; 8 \mathrm{~min}, 100 \% \mathrm{~A}$; and $13 \mathrm{~min}, 100 \% \mathrm{~A}$. The flow rate was set at $1.0 \mathrm{~mL} \mathrm{~min}^{-1}$. The temperature of the autosampler was $4{ }^{\circ} \mathrm{C}$, and injection volume was $5 \mu \mathrm{L}$. 


\subsubsection{Chemicals}

Ethanol (96\%) was purchased from J.T. Baker (Center Valley, PA, USA). Acetic acid (96\%) and potassium chloride were purchased from Merck (Kenilworth, NJ, USA), whereas hydrochloric acid (36\%) and sodium acetate (anhydrous) were obtained from Fisher Chemical (Fisher Scientific, MA, USA). Phosphoric acid ( $\geq 99 \%)$, Folin-Ciocalteu's phenol reagent, sodium carbonate, 2,2' -azino-bis(3-ethylbenzothiazoline-6-sulphonic acid) diammonium salt (ABTS), sodium fluoride, ascorbic acid (99\%), and Trolox (6-hydroxy-2,5,7,8-tetramethylchroman-2-carboxylic acid) were acquired from Sigma-Aldrich (St. Louis, MO, USA). Potassium persulfate $\left(\mathrm{K}_{2} \mathrm{~S}_{2} \mathrm{O}_{8}\right)$ and gallic acid ( $\geq 99 \%$ ) were purchased from Carl Roth (Karlsruhe, Germany). Methanol (HPLC-grade) was purchased from VWR Chemicals (Milan, Italy), and meta-phosphoric acid ( $\geq 99 \%)$ and monopotassium phosphate $(\geq 99 \%)$ were acquired from Thermo Fisher Scientific Inc. (Waltham, MA, USA). The ultrapure water was prepared with a Millli-Q-water purification system (EMD Millipore Corporation, Billerica, MA, USA).

\subsection{Mineral Element Analysis in Plant Tissues}

The analysis of macro- and micronutrients was performed by collecting a $5 \mathrm{~g}$ DW sample of leaves and roots from 4 randomly selected plants at 0 DAT and from each of the 4 replicates per treatment at 90 DAT. Nitrogen content was determined with an elemental analyzer (LECO Truspec, LECO Corporation, St. Joseph, MI, USA); method according to Dumas [46]. The other macro- (P, K, $\mathrm{Ca}, \mathrm{Mg}$ ) and microelements ( $\mathrm{S}, \mathrm{Fe}, \mathrm{Cu}, \mathrm{B}, \mathrm{Zn}, \mathrm{Mn}, \mathrm{Na}, \mathrm{Si})$ were analyzed with microwave-assisted acid digestion (EPA 3052 1996; [47]; Milestone Srl, Sorisole, BG, Italy Mod. UltraWave) using the inductively coupled plasma optical emission spectrometry (ICP-OES; [48]; Agilent, Santa Clara, CA, USA, Model 720).

\subsection{Statistical Analysis}

Significant differences between treatments were determined with a one-way analysis of variance (ANOVA) after that data were checked for normal distribution (Shapiro-Wilk normality test, $p>0.05$ ) and equality of variances (Bartlett's test, $p>0.05$ ). Mean separation was performed with the Dunnett test for $p<0.05$. This procedure is recommended when working with several treatments [49], as in this case. Data expressed in percentage were arcsine-transformed prior to the application of the ANOVA. All analyses were carried out in R v. 3.3.1. (R Development Core Team, Vienna, Austria, 2016). Values were expressed as mean \pm standard deviation (SD).

\section{Results}

\subsection{Plant Growth Parameters}

Biomass accumulation in strawberry leaves varied approximately between 1 and $5 \mathrm{~g}$ DW (Table 4 and Figure S2, supplementary material). Mix of amino acids (MAA)-treated plants showed a significantly lower leaf dry weight accumulation as compared to control. No significant differences were detected in the biomass accumulation in crown, shoots, and stolons of the differently treated plants (Table 4). Root biomass accumulation in untreated plants was generally low (0.6 g DW on average), whereas treatments with alfalfa protein hydrolysate (APH), macroseaweed extract (SEA), microalga hydrolysate (SPI), B-group vitamins (VIT), and chitosan (CHI) significantly enhanced biomass accumulation in the root system (e.g., approximately 7-fold in APH-treated plants). Fruit dry matter accumulation appeared to be significantly reduced in MAA- and amino acids combined

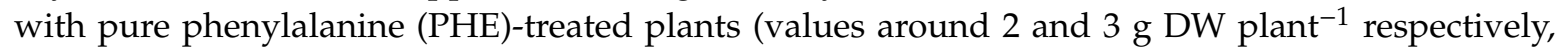
approximately $-40 \%$ as compared to control) and increased in CHI- and Siliforce ${ }^{\circledR}$ (SIL)-treated plants (approximately by $20 \%$ ). All biostimulant-treated plants (with the exception of SIL) resulted in being characterized by a higher relative share of dry matter allocation in the root system at the end of the growth cycle $(+40 \%-80 \%)$ as compared to control (Figure 2$)$. 
Table 4. Accumulated biomass in different plant organs (g DW plant ${ }^{-1}$ ) as affected by biostimulant applications.

\begin{tabular}{cccccc}
\hline Treatment & Leaves & Shoots and Stolons & Crowns & Roots & Fruits \\
\hline CON & $3.35 \pm 1.32^{1}$ & $0.87 \pm 0.38$ & $0.04 \pm 0.25$ & $0.59 \pm 0.87$ & $4.01 \pm 0.19$ \\
HAL & $3.17 \pm 2.36$ & $0.47 \pm 0.20$ & $0.07 \pm 0.16$ & $2.26 \pm 1.72$ & $3.96 \pm 0.15$ \\
APH & $3.47 \pm 2.08$ & $0.85 \pm 0.30$ & $0.13 \pm 0.21$ & $4.19 \pm 0.34^{* * *}$ & $4.31 \pm 0.15$ \\
SEA & $2.05 \pm 1.16$ & $0.59 \pm 0.22$ & $0.08 \pm 0.13$ & $3.06 \pm 1.49^{*}$ & $4.26 \pm 0.33$ \\
SPI & $4.85 \pm 1.81$ & $0.83 \pm 0.21$ & $0.25 \pm 0.25$ & $2.91 \pm 1.19^{*}$ & $3.76 \pm 0.20$ \\
MAA & $0.87 \pm 0.78^{*}$ & $0.56 \pm 0.39$ & $0.10 \pm 0.22$ & $0.79 \pm 0.97$ & $1.98 \pm 0.58^{* * *}$ \\
PHE & $1.70 \pm 1.47$ & $0.45 \pm 0.37$ & $0.00 \pm 0.17$ & $2.00 \pm 1.70$ & $3.01 \pm 0.16^{* * *}$ \\
ZIN & $2.40 \pm 1.00$ & $0.65 \pm 0.26$ & $0.01 \pm 0.22$ & $1.56 \pm 0.64$ & $3.79 \pm 0.08$ \\
VIT & $5.30 \pm 1.17$ & $1.16 \pm 0.21$ & $0.33 \pm 0.39$ & $4.13 \pm 2.29 * *$ & $4.32 \pm 0.12$ \\
CHI & $4.81 \pm 0.85$ & $0.86 \pm 0.42$ & $0.58 \pm 0.37$ & $3.75 \pm 1.85^{* *}$ & $5.05 \pm 0.39^{* * *}$ \\
SIL & $3.14 \pm 1.42$ & $0.69 \pm 0.44$ & $0.12 \pm 0.31$ & $1.49 \pm 1.19$ & $4.64 \pm 0.57^{*}$ \\
\hline
\end{tabular}

1 Means \pm SD. Values followed by asterisk indicate significant differences between a single treatment group and control group, according to Dunnett's test $(n=4)$. ${ }^{* * *} p<0.001 ;{ }^{* *} p<0.01 ;{ }^{*} p<0.05$; values followed by no asterisk indicate absence of any significant differences. Treatments legend: $\mathrm{CON}$, control; HAL, humic acids; APH, alfalfa protein hydrolysate; SEA, macroseaweed extract; SPI, microalga hydrolysate; MAA, mix of amino acids; PHE, MAA combined with pure phenylalanine; ZIN, MAA combined with zinc; VIT, B-group vitamins; CHI, chitosan; SIL, Siliforce ${ }^{\circledR}$.

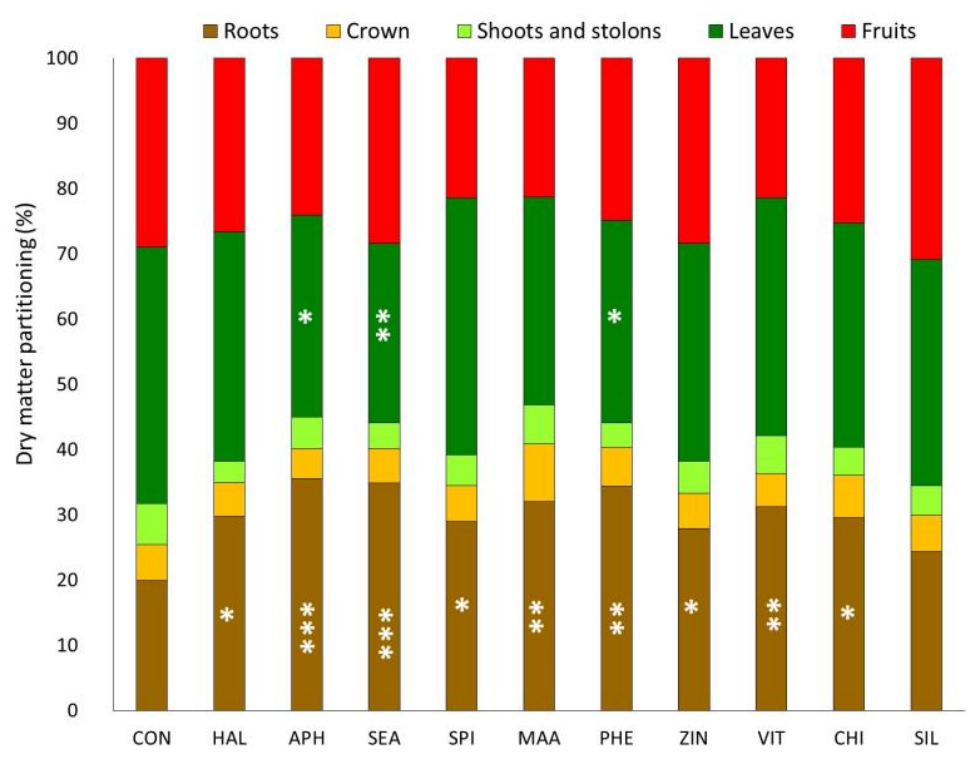

Figure 2. Dry matter distribution in strawberry plant organs treated with different biostimulant products and water (control). $n=4$. The asterisk indicates significant differences between a single treatment group and control group within each plant organ, according to Dunnett's test. ${ }^{* *} p<0.001$; ${ }^{* *} p<0.01 ;{ }^{*} p<0.05$; no asterisk indicates absence of any significant differences. Treatments legend: CON, control; HAL, humic acids; APH, alfalfa protein hydrolysate; SEA, macroseaweed extract; SPI, microalga hydrolysate; MAA, mix of amino acids; PHE, MAA combined with pure phenylalanine; ZIN, MAA combined with zinc; VIT, B-group vitamins; CHI, chitosan; SIL, Siliforce ${ }^{\circledR}$.

Relative leaf dry matter allocation was significantly lower in SEA-, APH-, and PHE-treated plants, whereas in fruits, crown, shoots, and stolons, there were no significant differences as compared to the control. At different phases of the experimental cycle, the leaf area of plants treated with APH, VIT, CHI, and SIL was significantly larger than control $(+15 \%-30 \%)$, whereas humic acids (HAL) and PHE applications significantly reduced the leaf surface (about $80 \mathrm{~cm}^{2}$ compared to $100 \mathrm{~cm}^{2}$ in control plants) at the end of the experiment (Figure 3). 


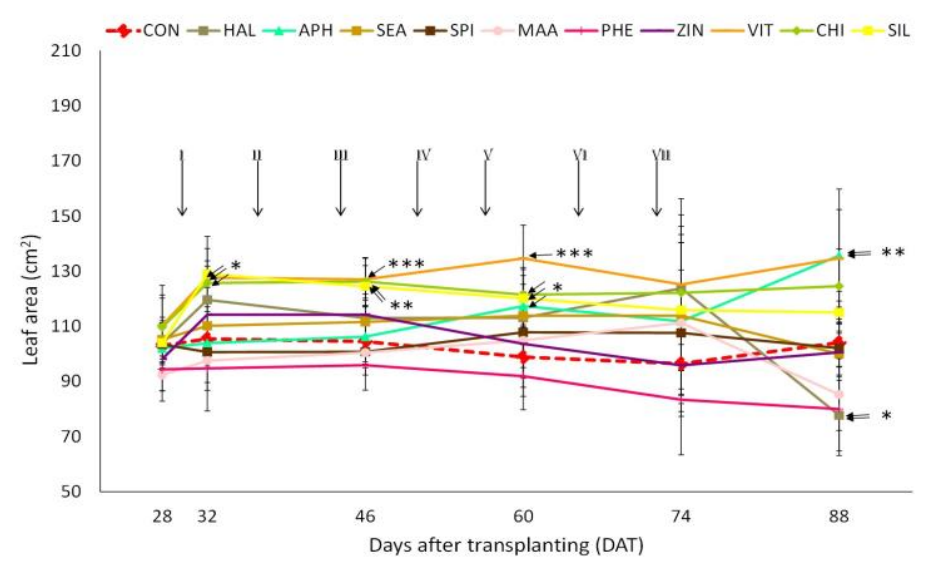

Figure 3. Leaf area dynamics during the period from 28 to 88 days after transplanting (DAT) (end of growth and production) in strawberry plants treated with different biostimulant products and water (control). Arrows indicate when the 7 biostimulant applications were performed. Vertical bars indicate mean $\pm \mathrm{SD}, n=4$. The asterisk indicates significant differences according to Dunnett's test. ${ }^{* * *} p<0.001$; ${ }^{* *} p<0.01 ;{ }^{*} p<0.05$; no asterisk indicates absence of any significant differences.

\subsection{Nutrient Concentration in Plant Tissues and SPAD Values}

Macronutrient concentrations in strawberry leaves were not affected by the tested biostimulants (Table 5). Nitrogen content ranged between $2.4 \%$ and $2.7 \%$ DW, whereas phosphorus concentration was around $0.5 \%$ DW. Leaf content for potassium and calcium was approximately $2.6 \%$ and $2.2 \%$, respectively. As for the magnesium $(\mathrm{Mg})$ and sulfur $(\mathrm{S})$, their concentrations were found around $0.4 \%$ $(\mathrm{Mg})$ and $0.2 \%(\mathrm{~S})$. The micronutrients zinc $(\mathrm{Zn})$ and silicon (Si) presented higher concentrations in leaves of some of the tested biostimulants (Table 6). In detail, Zn was found significantly higher in leaves of MAA combined with zinc (ZIN)- and SIL-treated plants ( $+338 \%$ and $+190 \%$ as compared to control, respectively), whereas Si content in strawberry leaves was significantly increased in plants treated with APH, ZIN and SIL, with values higher than $600 \mathrm{mg} \mathrm{kg}^{-1} \mathrm{DW}$ compared to around $400 \mathrm{mg} \mathrm{kg}^{-1} \mathrm{DW}$ of the control leaves. No significant differences were observed for the other micronutrient contents.

Macronutrient concentrations were not affected by biostimulant applications also at root level (Table 7). As far as the micronutrient concentrations are concerned, root boron content was found significantly higher $(+20-30 \%)$ in control plants as compared to the majority of the biostimulant-treated plants (Table 8). Iron ( $\mathrm{Fe}$ ) content in root tissues was promoted by SPI and VIT applications $(+273 \%$ and $+202 \%$ as compared to control, respectively). Moreover, the $\mathrm{Zn}$ concentration was significantly increased in roots of ZIN-treated plants $\left(140 \mathrm{mg} \mathrm{kg}^{-1} \mathrm{DW}\right.$ in comparison to $77 \mathrm{mg} \mathrm{kg}^{-1} \mathrm{DW}$ in control roots). Finally, Si content was found to be higher in roots treated with HAL, SEA, SPI, ZIN, VIT, CHI, and SIL (around $+75 \%$ as compared to control). 
Table 5. Macronutrient concentrations in strawberry leaves at 90 DAT (days after transplanting) as affected by biostimulant applications.

\begin{tabular}{ccccccc}
\hline Treatment & $\mathbf{N}(\% \mathbf{D W})$ & $\mathbf{P}(\% \mathbf{D W})$ & $\mathbf{K}(\% \mathbf{D W})$ & $\mathbf{C a}(\% \mathbf{D W})$ & $\mathbf{M g}(\% \mathbf{D W})$ & $\mathbf{S}(\% \mathbf{D W})$ \\
\hline CON & $2.59 \pm 0.25^{1}$ & $0.51 \pm 0.04$ & $2.52 \pm 0.18$ & $2.37 \pm 0.15$ & $0.38 \pm 0.02$ & $0.22 \pm 0.03$ \\
HAL & $2.46 \pm 0.04$ & $0.52 \pm 0.05$ & $2.72 \pm 0.42$ & $2.27 \pm 0.27$ & $0.39 \pm 0.02$ & $0.22 \pm 0.03$ \\
APH & $2.60 \pm 0.27$ & $0.58 \pm 0.08$ & $2.64 \pm 0.12$ & $2.26 \pm 0.22$ & $0.38 \pm 0.01$ & $0.22 \pm 0.03$ \\
SEA & $2.56 \pm 0.17$ & $0.55 \pm 0.05$ & $2.81 \pm 0.38$ & $2.25 \pm 0.20$ & $0.39 \pm 0.03$ & $0.24 \pm 0.05$ \\
SPI & $2.49 \pm 0.35$ & $0.56 \pm 0.07$ & $2.58 \pm 0.23$ & $2.42 \pm 0.16$ & $0.42 \pm 0.04$ & $0.24 \pm 0.07$ \\
MAA & $2.56 \pm 0.09$ & $0.62 \pm 0.04$ & $2.59 \pm 0.12$ & $2.14 \pm 0.13$ & $0.38 \pm 0.03$ & $0.20 \pm 0.01$ \\
PHE & $2.74 \pm 0.39$ & $0.52 \pm 0.11$ & $2.77 \pm 0.08$ & $2.42 \pm 0.32$ & $0.40 \pm 0.03$ & $0.24 \pm 0.05$ \\
ZIN & $2.47 \pm 0.16$ & $0.52 \pm 0.09$ & $2.75 \pm 0.08$ & $2.16 \pm 0.24$ & $0.37 \pm 0.03$ & $0.21 \pm 0.05$ \\
VIT & $2.38 \pm 0.29$ & $0.62 \pm 0.02$ & $2.79 \pm 0.32$ & $2.24 \pm 0.18$ & $0.42 \pm 0.02$ & $0.19 \pm 0.03$ \\
CHI & $2.36 \pm 0.17$ & $0.54 \pm 0.05$ & $2.69 \pm 0.15$ & $2.10 \pm 0.15$ & $0.39 \pm 0.01$ & $0.20 \pm 0.01$ \\
SIL & $2.38 \pm 0.21$ & $0.51 \pm 0.06$ & $2.74 \pm 0.25$ & $2.16 \pm 0.15$ & $0.37 \pm 0.03$ & $0.18 \pm 0.03$
\end{tabular}

${ }^{1}$ Means \pm S.D. Values followed by asterisk indicate significant differences between a single treatment group and control group, according to Dunnett's test $(n=4)$. ${ }^{* * *} p<0.001 ; * * 0<0.01$; $* x<0.05$; no asterisk indicates absence of any significant differences.

Table 6. Micronutrient concentrations in strawberry leaves at 90 DAT (days after transplanting) as affected by biostimulant applications.

\begin{tabular}{|c|c|c|c|c|c|c|c|}
\hline Treatment & $B\left(\mathrm{mg} \mathrm{kg}^{-1} \mathrm{DW}\right)$ & $\mathrm{Fe}\left(\mathrm{mg} \mathrm{kg}{ }^{-1} \mathrm{DW}\right)$ & Mn (mg kg $\left.{ }^{-1} \mathrm{DW}\right)$ & $\mathrm{Cu}\left(\mathrm{mg} \mathrm{kg}^{-1} \mathrm{DW}\right)$ & $\mathrm{Zn}\left(\mathrm{mg} \mathrm{kg}^{-1} \mathrm{DW}\right)$ & $\mathrm{Na}\left(\mathrm{mg} \mathrm{kg}^{-1} \mathrm{DW}\right)$ & Si (mg kg-1 DW) \\
\hline $\mathrm{CON}$ & $66.58 \pm 10.93$ & $81.65 \pm 4.89$ & $381.88 \pm 107.48$ & $7.00 \pm 0.00$ & $28.93 \pm 3.01$ & $240.12 \pm 84.80$ & $416.88 \pm 61.75$ \\
\hline HAL & $58.75 \pm 3.78$ & $111.15 \pm 28.87$ & $331.58 \pm 47.57$ & $10.10 \pm 3.59$ & $34.53 \pm 10.27$ & $319.56 \pm 45.58$ & $538.53 \pm 158.67$ \\
\hline $\mathrm{APH}$ & $60.55 \pm 7.41$ & $102.68 \pm 32.96$ & $355.08 \pm 60.70$ & $7.35 \pm 0.64$ & $25.98 \pm 1.79$ & $251.92 \pm 126.22$ & $782.65 \pm 68.74^{* * *}$ \\
\hline SEA & $55.93 \pm 3.32$ & $197.75 \pm 143.89$ & $300.90 \pm 101.74$ & $7.15 \pm 0.30$ & $28.73 \pm 6.49$ & $363.06 \pm 74.44$ & $424.30 \pm 18.28$ \\
\hline SPI & $62.08 \pm 16.99$ & $114.60 \pm 13.64$ & $378.10 \pm 104.30$ & $7.00 \pm 0.00$ & $31.75 \pm 2.32$ & $327.93 \pm 127.08$ & $471.50 \pm 33.98$ \\
\hline MAA & $61.18 \pm 5.57$ & $800.55 \pm 1348.74$ & $367.60 \pm 57.87$ & $9.53 \pm 3.18$ & $34.88 \pm 7.92$ & $243.16 \pm 66.33$ & $457.83 \pm 113.69$ \\
\hline PHE & $61.75 \pm 13.01$ & $94.93 \pm 16.11$ & $375.75 \pm 117.59$ & $7.38 \pm 0.75$ & $31.38 \pm 4.81$ & $440.30 \pm 262.85$ & $480.68 \pm 146.04$ \\
\hline ZIN & $59.43 \pm 6.13$ & $310.85 \pm 332.71$ & $285.73 \pm 83.13$ & $7.65 \pm 1.23$ & $127.43 \pm 13.95^{* * *}$ & $270.27 \pm 68.68$ & $624.68 \pm 98.52^{* *}$ \\
\hline VIT & $62.40 \pm 5.67$ & $91.75 \pm 13.21$ & $347.75 \pm 59.23$ & $7.58 \pm 0.67$ & $36.15 \pm 4.11$ & $234.82 \pm 79.06$ & $398.65 \pm 71.72$ \\
\hline $\mathrm{CHI}$ & $59.50 \pm 4.46$ & $115.40 \pm 43.02$ & $393.08 \pm 38.55$ & $7.13 \pm 0.25$ & $30.90 \pm 0.85$ & $218.92 \pm 20.99$ & $487.33 \pm 110.15$ \\
\hline SIL & $60.40 \pm 4.43$ & $93.48 \pm 23.08$ & $366.53 \pm 87.71$ & $7.23 \pm 0.45$ & $83.80 \pm 13.61^{* * *}$ & $254.18 \pm 126.09$ & $689.13 \pm 41.81^{* * * *}$ \\
\hline
\end{tabular}

${ }^{1}$ Means \pm S.D. Values followed by asterisk indicate significant differen 
Table 7. Macronutrient concentrations in strawberry roots at 90 DAT (days after transplanting) as affected by biostimulant application.

\begin{tabular}{ccccccc}
\hline Treatment & $\mathbf{N}(\% \mathbf{D W})$ & $\mathbf{P}(\% \mathbf{D W})$ & $\mathbf{K}(\% \mathbf{D W})$ & $\mathbf{C a}(\% \mathbf{D W})$ & $\mathbf{M g}(\% \mathbf{D W})$ & $\mathbf{S}(\% \mathbf{D W})$ \\
\hline CON & $1.44 \pm 0.12^{1}$ & $0.15 \pm 0.03$ & $0.49 \pm 0.18$ & $1.60 \pm 0.22$ & $0.21 \pm 0.02$ & $0.35 \pm 0.03$ \\
HAL & $1.28 \pm 0.17$ & $0.13 \pm 0.02$ & $0.46 \pm 0.16$ & $1.74 \pm 0.17$ & $0.22 \pm 0.01$ & $0.37 \pm 0.08$ \\
APH & $1.45 \pm 0.14$ & $0.14 \pm 0.05$ & $0.44 \pm 0.22$ & $1.85 \pm 0.29$ & $0.23 \pm 0.05$ & $0.45 \pm 0.09$ \\
SEA & $1.41 \pm 0.15$ & $0.14 \pm 0.03$ & $0.40 \pm 0.08$ & $1.97 \pm 0.16$ & $0.23 \pm 0.02$ & $0.50 \pm 0.08$ \\
SPI & $1.35 \pm 0.17$ & $0.13 \pm 0.02$ & $0.43 \pm 0.09$ & $1.77 \pm 0.16$ & $0.22 \pm 0.03$ & $0.40 \pm 0.07$ \\
MAA & $1.65 \pm 0.18$ & $0.18 \pm 0.03$ & $0.49 \pm 0.07$ & $1.68 \pm 0.21$ & $0.22 \pm 0.03$ & $0.46 \pm 0.13$ \\
PHE & $1.39 \pm 0.17$ & $0.14 \pm 0.02$ & $0.48 \pm 0.18$ & $1.86 \pm 0.23$ & $0.20 \pm 0.02$ & $0.45 \pm 0.13$ \\
ZIN & $1.45 \pm 0.08$ & $0.15 \pm 0.02$ & $0.50 \pm 0.14$ & $1.82 \pm 0.17$ & $0.24 \pm 0.04$ & $0.43 \pm 0.07$ \\
VIT & $1.44 \pm 0.08$ & $0.14 \pm 0.02$ & $0.45 \pm 0.09$ & $1.91 \pm 0.35$ & $0.26 \pm 0.01$ & $0.57 \pm 0.28$ \\
CHI & $1.26 \pm 0.19$ & $0.13 \pm 0.03$ & $0.39 \pm 0.03$ & $1.93 \pm 0.17$ & $0.23 \pm 0.01$ & $0.46 \pm 0.12$ \\
SIL & $1.40 \pm 0.07$ & $0.17 \pm 0.03$ & $0.59 \pm 0.18$ & $1.69 \pm 0.25$ & $0.23 \pm 0.02$ & $0.41 \pm 0.13$
\end{tabular}

${ }^{1}$ Means \pm S.D. Values followed by asterisk indicate significant differences between a single treatment group and control group, according to Dunnett's test $(n=4)$. ${ }^{* * *} p<0.001 ; * * p<0.01 ;$ $* p<0.05$; no asterisk indicates absence of any significant differences.

Table 8. Micronutrient concentrations in strawberry roots at 90 DAT (days after transplanting) as affected by biostimulant application.

\begin{tabular}{|c|c|c|c|c|c|c|c|}
\hline Treatment & $B\left(\mathrm{mg} \mathrm{kg}^{-1} \mathrm{DW}\right)$ & Fe (mg kg-1 DW) & Mn (mg kg-1 DW) & $\mathrm{Cu}\left(\mathrm{mg} \mathrm{kg}^{-1} \mathrm{DW}\right)$ & Zn (mg kg $\left.{ }^{-1} \mathrm{DW}\right)$ & $\mathrm{Na}\left(\mathrm{mg} \mathrm{kg}^{-1} \mathrm{DW}\right)$ & Si (mg kg $\left.{ }^{-1} \mathrm{DW}\right)$ \\
\hline $\mathrm{CON}$ & $17.28 \pm 2.29$ & $484.63 \pm 94.84$ & $56,25 \pm 23,07$ & $80.08 \pm 53.24$ & $77.08 \pm 43.06$ & $702.14 \pm 81.07$ & $350.25 \pm 78.52$ \\
\hline HAL & $13.10 \pm 3.45^{*}$ & $1227.43 \pm 538.00$ & $51,43 \pm 22,80$ & $98.13 \pm 73.45$ & $67.48 \pm 56.12$ & $662.19 \pm 118.41$ & $528.63 \pm 97.22 *$ \\
\hline $\mathrm{APH}$ & $11.43 \pm 2.66^{* *}$ & $620.83 \pm 215.52$ & $81,40 \pm 12,66$ & $52.65 \pm 19.62$ & $44.98 \pm 30.09$ & $624.75 \pm 77.51$ & $444.93 \pm 92.27$ \\
\hline SEA & $10.90 \pm 0.98^{* * *}$ & $724.53 \pm 214.65$ & $55,35 \pm 38,78$ & $146.40 \pm 84.29$ & $42.95 \pm 15.41$ & $681.68 \pm 81.97$ & $538.88 \pm 105.99 *$ \\
\hline SPI & $12.35 \pm 2.64^{* *}$ & $1807.48 \pm 1745.77^{* *}$ & $75,45 \pm 31,44$ & $68.90 \pm 52.69$ & $57.78 \pm 38.74$ & $624.80 \pm 141.86$ & $683.63 \pm 182.23^{* * *}$ \\
\hline MAA & $13.73 \pm 3.36$ & $648.95 \pm 150.92$ & $70,58 \pm 19,96$ & $207.95 \pm 222.50$ & $127.05 \pm 94.10$ & $579.94 \pm 100.10$ & $515.35 \pm 127.19$ \\
\hline PHE & $12.98 \pm 1.78^{*}$ & $691.78 \pm 309.30$ & $97,50 \pm 88,66$ & $83.70 \pm 113.54$ & $40.78 \pm 15.81$ & $586.40 \pm 61.30$ & $461.80 \pm 117.93$ \\
\hline ZIN & $12.33 \pm 2.46^{* *}$ & $808.08 \pm 157.22$ & $70,25 \pm 38,06$ & $69.63 \pm 52.43$ & $139.78 \pm 32.20$ * & $643.41 \pm 191.04$ & $689.03 \pm 93.68 * * *$ \\
\hline VIT & $8.53 \pm 1.98^{* * *}$ & $1461.73 \pm 956.78$ * & $100,13 \pm 73,10$ & $228.33 \pm 63.72$ & $95.98 \pm 35.03$ & $600.22 \pm 90.50$ & $631.18 \pm 99.86^{* *}$ \\
\hline $\mathrm{CHI}$ & $10.33 \pm 2.76^{* * *}$ & $1079.63 \pm 661.56$ & $133,63 \pm 39,71$ & $80.23 \pm 41.43$ & $38.28 \pm 8.27$ & $655.94 \pm 19.66$ & $623.28 \pm 187.63^{* *}$ \\
\hline SIL & $12.68 \pm 1.91 *$ & $519.48 \pm 183.10$ & $55,30 \pm 29,18$ & $69.08 \pm 50.39$ & $67.98 \pm 22.73$ & $565.72 \pm 98.53$ & $590.98 \pm 57.86^{* *}$ \\
\hline
\end{tabular}

Mean \pm S.D. Values followed by asterisk indicate significant differen 
SPAD values were not affected by biostimulant applications during most of the growing cycle. Only at the end of the experiment (88 DAT) was a significant higher SPAD value measured in plants treated with APH ( $+17 \%$ as compared to control) (Figure 4$)$.

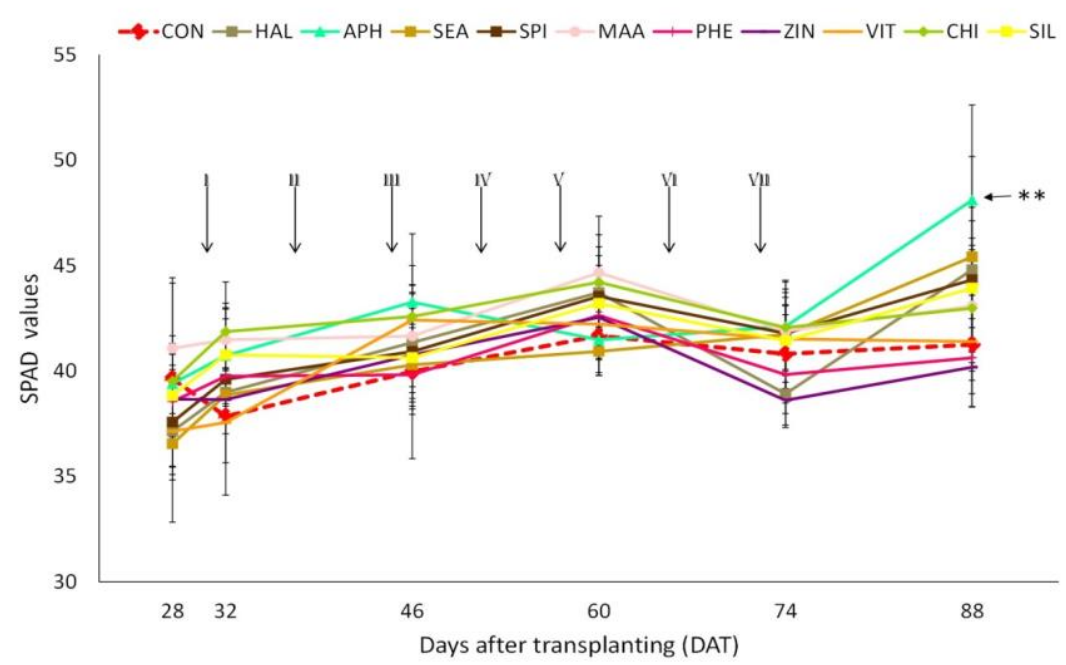

Figure 4. Chlorophyll content (as SPAD values) dynamics from 28 to 88 DAT (end of growth and production) in strawberry plants treated with different biostimulant products and water (control). Arrows indicate when the 7 biostimulant applications were performed. Vertical bars indicate mean \pm SD, $n=4$. The asterisk indicates significant differences according to Dunnett's test. ${ }^{* * *} p<0.001 ;{ }^{* *} p<0.01$; * $p<0.05$; no asterisk indicates absence of any significant differences.

\subsection{Leaf Gas Exchanges}

Before the fifth application (exactly at 57 DAT), a significantly higher leaf photosynthetic rate was measured for HAL-, ZIN-, and SIL-treated leaves (Figure 5A). After $24 \mathrm{~h}$ from the application, only SIL-treated leaves were still characterized by a significantly higher photosynthetic rate as compared to control $(+32 \%)$, whereas at $48 \mathrm{~h}$ from the treatments, none of the biostimulants tested showed a significantly higher rate than control plants. Biostimulant-treated plants were characterized by a higher intensity of transpiration (almost double as compared to control) immediately before and after the fifth application (Figure 5B). Only HAL-treated plants did not show any significant difference with control 24 and $48 \mathrm{~h}$ after the application.

\subsection{Yield, Harvest and Fruit Quality}

$\mathrm{CHI}$ - and SIL-treated plants were characterized by a significantly higher average fruit weight as compared to control (Table 9). Their number of fruits per plant did not differ with control, leading to a significant 10-15 g yield increment per plant. Conversely, applications with amino acids (MAA and PHE) decreased the mean fruit weight, the number of fruits per plant, and the final yield $(-49 \%$ and $-22 \%$ as compared to control). 


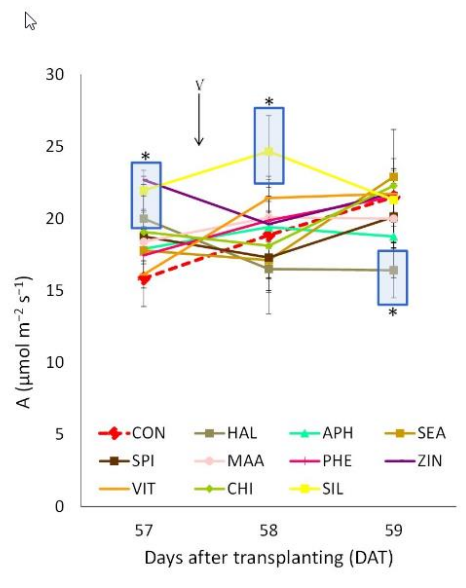

(a)

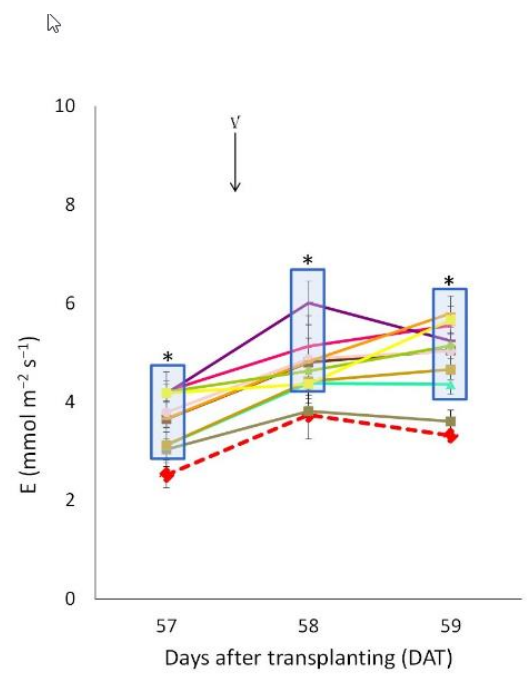

(b)

Figure 5. Photosynthetic (a) and transpiration (b) rates in strawberry leaves treated with different biostimulant products and water (control). 57 DAT: immediately before spray; 58 DAT: $24 \mathrm{~h}$ after spray; 59 DAT: $48 \mathrm{~h}$ after spray. Arrow indicates the fifth biostimulant application. Vertical bars indicate mean $\pm \mathrm{SD}, n=4$. Asterisk $\left(^{*}\right)$, and the blue rectangle in the background indicates the group of treatments that significantly differed from control according to Dunnett's test $(p<0.05)$; no asterisk indicates absence of any significant differences.

Table 9. Yield parameters (final yield, number of fruits per plant and mean fruit weight) as affected by biostimulant products.

\begin{tabular}{|c|c|c|c|}
\hline Treatment & Total Yield (g plant ${ }^{-1} \mathrm{FW}^{\mathrm{a}}$ ) & Number Fruits Plant ${ }^{-1}\left(\mathbf{N}^{\circ}\right)$ & Mean Fruit Weight (g FW) \\
\hline $\mathrm{CON}$ & $50.84 \pm 3.57^{1}$ & $7.75 \pm 0.25$ & $6.55 \pm 0.24$ \\
\hline HAL & $50.95 \pm 1.95$ & $7.42 \pm 0.72$ & $6.97 \pm 0.42$ \\
\hline $\mathrm{APH}$ & $51.67 \pm 2.90$ & $7.00 \pm 0.25$ & $7.43 \pm 0.46^{*}$ \\
\hline SEA & $53.57 \pm 1.17$ & $8.25 \pm 0.87$ & $6.52 \pm 0.40$ \\
\hline SPI & $51.05 \pm 7.71$ & $7.17 \pm 0.38$ & $7.16 \pm 0.07$ \\
\hline MAA & $25.95 \pm 4.69^{* * *}$ & $4.50 \pm 0.66^{* * *}$ & $5.74 \pm 0.76 *$ \\
\hline PHE & $39.59 \pm 2.73 * *$ & $6.58 \pm 0.38 *$ & $6.08 \pm 0.43$ \\
\hline ZIN & $47.51 \pm 1.89$ & $7.17 \pm 0.58$ & $6.82 \pm 0.84$ \\
\hline VIT & $54.58 \pm 2.94$ & $8.25 \pm 0.25$ & $6.60 \pm 0.09$ \\
\hline $\mathrm{CHI}$ & $64.88 \pm 3.02 * * *$ & $8.42 \pm 0.80$ & $7.72 \pm 0.22 * *$ \\
\hline SIL & $59.57 \pm 6.29 *$ & $7.92 \pm 0.88$ & $7.54 \pm 0.11 *$ \\
\hline
\end{tabular}

${ }^{\text {a }}$ FW: fresh weight; ${ }^{1}$ Means \pm SD. Values followed by asterisk indicate significant differences between a single treatment group and control group, according to Dunnett's test $(n=4) .{ }^{* * *} p<0.001$; ${ }^{* *} p<0.01 ;{ }^{*} p<0.05$; no asterisk indicates absence of any significant differences.

The majority of strawberries (around $60 \%$ of the total yield per plant) were picked during the middle period of the harvesting time, corresponding to the second of a 3-week harvest period (Figure 6). VIT- and MAA-treated plants were characterized by a larger share of fruits picked at the beginning of the harvest, therefore showing an overall earlier ripening of the strawberries. Conversely, SEA-, SPI-, and CHI-treated plants showed a delayed maturation process as suggested by the higher share of fruits that were picked during the last period of the harvest. 


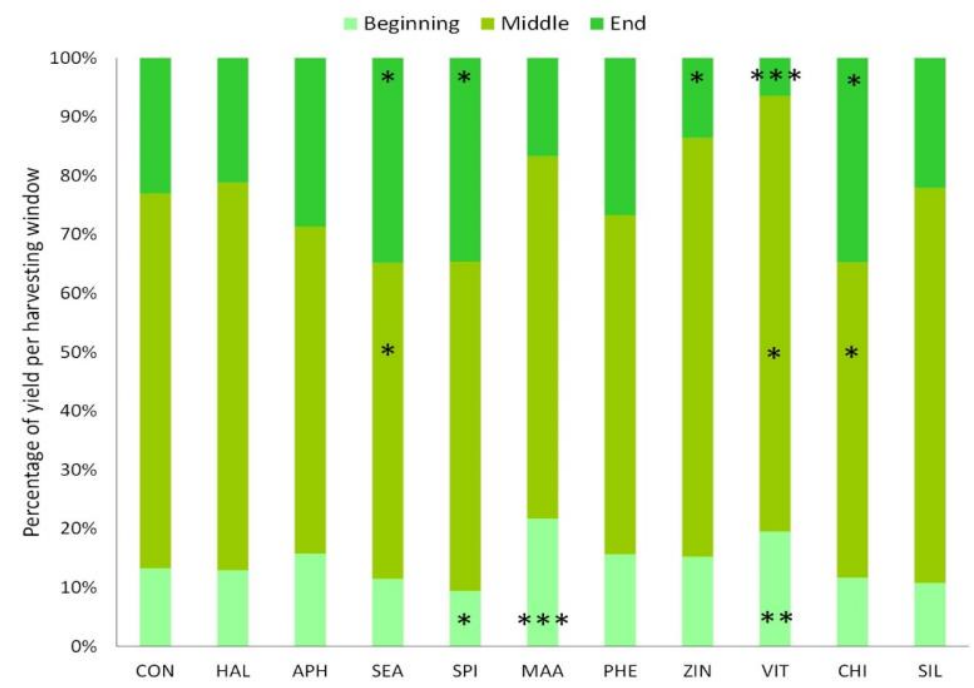

Figure 6. Percentage of the total yield per plant harvested during the three harvesting windows (beginning, middle, and end). $n=4$. Asterisk indicates significant differences between a single treatment group and control group within a harvesting window, according to Dunnett's test. ${ }^{* *} p<0.001$; ** $p<0.01 ; * p<0.05$; no asterisk indicates absence of any significant differences.

Strawberry flesh firmness ranged between 0.5 and $0.8 \mathrm{~kg} \mathrm{~cm}^{-2}$ (Table 10). Fruits from CHI-treated plants were characterized by significantly firmer pulp as compared to control $(+18 \%)$, whereas SPI-treated strawberries were significantly softer and sourer $\left(10.1 \mathrm{~g} \mathrm{~L}^{-1} \mathrm{TA}\right)$. Total soluble solids were generally increased by the biostimulant applications, with MAA-treated strawberries being those presenting the highest sugars accumulation $\left(8.7^{\circ}\right.$ Brix TSS, Table 8$)$. Chroma values $\left(C^{*}\right)$ were significantly higher in fruits treated with HAL, APH, SEA, and ZIN (around $+18 \%$ in comparison to control), indicating fruits with a brighter red coloration (Table 10), whereas no significant differences in fruit hue angle were detected.

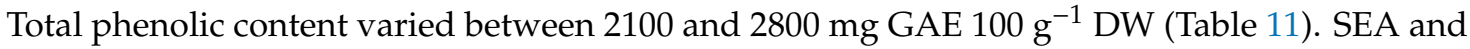
APH applications significantly enhanced the final total phenolic content of mature strawberry fruits (+20\% as compared to control). Total anthocyanin content (TAC) in fruits was not significantly affected by biostimulant applications (Table 11), even though HAL, APH, and SEA were among those treatments characterized by the highest anthocyanin accumulation. The fruit antioxidant potential measured as ABTS was not altered significantly by the treatments, whereas the ascorbic acid concentration was significantly reduced by both biostimulant products containing the zinc mineral element such as ZIN and SIL ( $-24 \%$ and $-19 \%$ as compared to control, respectively) (Table 11$)$. 
Table 10. Fruit quality traits (FF—firmness; TSS—-total soluble solids; TA—titratable acidity and color parameters: $C^{*}$ —chroma; $h^{\circ}$-hue angle) as affected by biostimulant products.

\begin{tabular}{cccccc}
\hline Treatment & FF $\left(\mathbf{k g ~ c m}^{-\mathbf{2}}\right)$ & TSS $^{\circ}$ Brix $)$ & TA $\left(\mathbf{g ~ L}^{-\mathbf{1}}\right)$ & $\mathbf{C}^{*}$ & $\mathbf{h}^{\circ}$ \\
\hline CON & $0.71 \pm 0.02^{1}$ & $7.07 \pm 0.06$ & $9.11 \pm 0.09$ & $27.41 \pm 1.36$ & $18.31 \pm 3.46$ \\
HAL & $0.69 \pm 0.02$ & $7.73 \pm 0.61$ & $9.32 \pm 0.08$ & $31.58 \pm 2.71 *$ & $17.72 \pm 3.90$ \\
APH & $0.73 \pm 0.02$ & $7.07 \pm 0.51$ & $9.48 \pm 0.18$ & $34.51 \pm 2.54 * * *$ & $17.28 \pm 3.70$ \\
SEA & $0.72 \pm 0.01$ & $7.73 \pm 0.50$ & $9.74 \pm 0.19$ & $34.72 \pm 3.74 * * *$ & $18.68 \pm 2.01$ \\
SPI & $0.58 \pm 0.09 * *$ & $7.03 \pm 0.15$ & $10.19 \pm 0.99 *$ & $29.89 \pm 1.07$ & $16.13 \pm 2.84$ \\
MAA & $0.73 \pm 0.04$ & $8.70 \pm 0.70 * * *$ & $8.66 \pm 0.40$ & $30.06 \pm 0.90$ & $16.98 \pm 0.63$ \\
PHE & $0.72 \pm 0.03$ & $7.23 \pm 0.25$ & $9.60 \pm 0.29$ & $28.69 \pm 3.23$ & $16.23 \pm 0.80$ \\
ZIN & $0.71 \pm 0.03$ & $7.97 \pm 0.2 *$ & $9.44 \pm 0.11$ & $32.86 \pm 2.37 * *$ & $17.03 \pm 4.61$ \\
VIT & $0.74 \pm 0.05$ & $7.80 \pm 0.44^{*}$ & $8.79 \pm 0.55$ & $30.25 \pm 1.99$ & $14.38 \pm 3.18$ \\
CHI & $0.84 \pm 0.01 * *$ & $6.97 \pm 0.15$ & $8.72 \pm 1.00$ & $29.05 \pm 1.81$ & $16.94 \pm 2.84$ \\
SIL & $0.73 \pm 0.11$ & $7.37 \pm 0.15$ & $9.34 \pm 0.27$ & $29.75 \pm 1.04$ & $17.08 \pm 1.55$ \\
\hline
\end{tabular}

${ }^{1}$ Means \pm SD. Values followed by asterisk indicate significant differences between a single treatment group and control group, according to Dunnett's test $(n=4) .{ }^{* * *} p<0.001 ; * * 0.01$; ${ }^{*} p<0.05$; no asterisk indicates absence of any significant differences.

Table 11. Fruit nutraceutical values (TPC—-total phenolic content; TAC—-total anthocyanin content; ABTS—antioxidant potential; AA—ascorbic acid) as affected by biostimulant products.

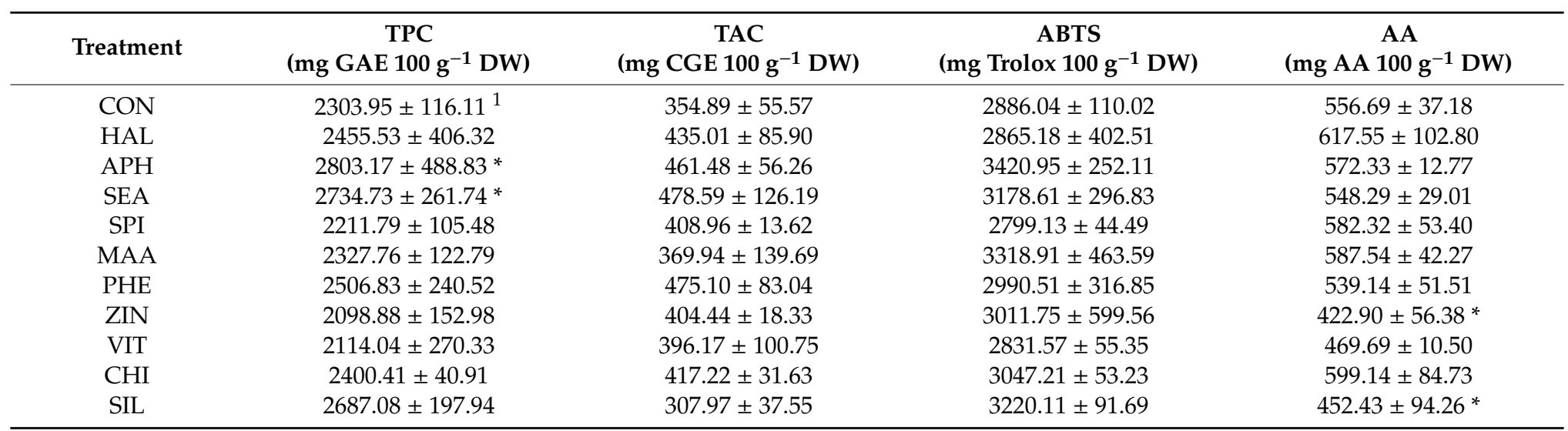

${ }^{1}$ Means \pm SD. Values followed by asterisk indicate significant differences between a single treatment group and control group, according to Dunnett's test $(n=4)$. ${ }^{* * *} p<0.001 ; * * p<0.01$; ${ }^{*} p<0.05$; no asterisk indicates absence of any significant differences. 


\section{Discussion}

Abiotic stresses, including nutrient limitation, are generally the cause of a reduced plant growth and final yield [50]. Under the imposed experimental conditions, soilless cultivated strawberry plants were characterized by vegetative and reproductive performances that were below the standard for similar cultivation systems and cultivar [51,52]. This was also suggested by values of the leaf area to yield ratio that were found below $3 \mathrm{~cm}^{2} \mathrm{~g}^{-1}$, under the threshold considered as indicative of a good vegetative-reproductive balance for strawberry [53]. Despite the limited supply of nutrients to the plants, which consisted of a single fertigation done one week after transplant (Table 1), macronutrient levels in leaves and roots (Tables 5 and 7) were found within the range of sufficiency for strawberry plants as reported in the literature [54,55]. Only nitrogen level was found to be lower (1.4\% on average) than the concentration range found in strawberry roots of the cultivar 'Selva' grown under standard conditions (around 2.4\%) [56]. Moreover, none of the applied biostimulants induced significant changes in the final macronutrient concentrations. Differently, some of the micronutrients (e.g., Fe, $\mathrm{Zn}$, and $\mathrm{Si}$ ) were found at a higher concentration in leaves and roots of plants treated with specific biostimulant compounds (Tables 6 and 8). More in detail, SPI-treated plants presented a higher Fe accumulation in the root system, probably as a consequence of the rhizosphere acidification promoted by selected metabolites included in the seaweed extract (e.g., kahydrin) that resulted in a more efficient mobilization and assimilation of the acid-soluble ions, including iron. A similar mechanism of Fe chelation following seaweed application was described by Spinelli et al. [19] on strawberry. ZIN and SIL applications resulted in higher concentrations of Zn and Si in leaves and roots (Tables 6 and 8). This result can be explained as the consequence of the direct supply of $\mathrm{Zn}$ and Si obtained by the application of both biostimulant treatments. Moreover, prior studies have highlighted the importance of amino acids (included in the ZIN formulation) as metal-chelating agents and carriers of micronutrients [57]. Regarding the lower root boron content observed in treated plants, Kaya et al. [58] reported that $\mathrm{Si}$ supply to tomato plants reduced boron concentration in plant tissues as a consequence of the B immobilization caused by the formation of boron-silicate complexes in the soil. Moreover, $\mathrm{B}$ availability is generally decreased under higher soil $\mathrm{pH}$ [59]. Although the substrate $\mathrm{pH}$ at the end of the experiment was not measured, biostimulant applications could have slightly enhanced soil $\mathrm{pH}$, therefore limiting B availability for the plants $[39,60]$.

Under the described growing and nutrient conditions, the use of selected biostimulants had a positive effect on strawberry plant growth and fruit yield. APH treatment enhanced biomass accumulation in roots, leaf area, and chlorophyll concentration (Table 4; Figures 3 and 4). These results reflect those of Ertani et al. [61] and Rouphael et al. [62] on pepper and tomato, respectively. The mode of action of the protein hydrolysates is likely to be linked to different plant physiological mechanisms, which include the stimulation of key enzymes involved in both the primary and secondary metabolisms, the hormone-like function of several components of the protein hydrolysate, and the indirect stimulation of the biological activities of the plant-associate microbes [63]. B-group vitamins were also effective in increasing leaf area and root growth (Figure 3 and Table 4). Vitamin B1 (thiamine) is an important cofactor involved in many primary metabolic processes (glycolysis, pentose phosphate pathway, and tricarboxylic acid cycle) $[64,65]$, explaining therefore the enhanced growth performances shown by the treated plants under suboptimal growing conditions. CHI and SIL applications improved both above- and belowground growth and yield performances (Figure 3; Tables 4 and 9). These findings are consistent with those obtained by Mukta et al. [66] and by Hajiboland et al. [67] on chitosan- and silicon-treated strawberry plants and are probably linked with the enhanced stress tolerance shown by the treated plants $[68,69]$. As shown in Figure 5, biostimulants containing zinc (ZIN and SIL) and HAL were found to be able to enhance leaf photosynthesis. Zinc-metalloenzymes are important for the activity of the carboxylation process key enzyme (Rubisco) [70,71]. Considering that Zn-deficiency reduces the photosynthetic activity of plants [72], the enhanced photosynthetic performances characterizing ZIN- and SIL-treated plants could be therefore explained with their higher zinc concentration in leaves (Table 6). 
Biostimulants have been also claimed to improve the quality attributes of horticultural products. The definition of quality of fruit and vegetable is considered extremely dynamic and involves a large number of intrinsic and extrinsic characteristics, including socioeconomic aspects linked to consumers' perceptions and acceptance of the products [73]. The potential role of plant biostimulants in enhancing the quality of greenhouse vegetables has been recently reviewed by Rouphael et al. [74]. In the present experiment, primary fruit quality attributes were slightly affected by the biostimulant applications (Table 10). Chitosan was found to be able to enhance flesh firmness with potential consequences on the shelf life period extension of treated fruits. Similar results were also obtained by Bhaskara Reddy et al. [75] and Hernández-Muñoz et al. [76] on strawberry (different cultivars). Treatments with amino acids and B-group vitamins led to an earlier ripening of the fruits (Figure 6) and to strawberries with higher sugar content (Table 10), a finding that was also described by Khan et al. [77] on grape fruits. Alfalfa protein hydrolysate and seaweed extracts improved the final coloration and the phenolic concentration in strawberry fruit at harvest (Tables 10 and 11). These results confirm the capacity of both biostimulants to interfere with the phenylpropanoid pathway, leading to more colored and stress-resistant crops $[21,27,78,79]$. Finally, a reduction in ascorbic acid level in fruits treated with biostimulants containing zinc (ZIN and SIL) was recorded (Table 11). This effect might be due to the inhibitory action of selected metals (e.g., zinc and copper) on the enzyme activity of ascorbic acid metabolism as also shown by Olkhovych et al. [80] on other species.

\section{Conclusions}

The aim of the present research was to examine if the application of different biostimulants could help the growth and yield performances of soilless cultivated strawberry plants under limited nutrient availability. The main findings suggest that selected biostimulants (i.e., alfalfa protein hydrolysate, B-group vitamins, chitosan, and silicon) could be effective in stimulate vegetative growth and final fruit yield. Moreover, biostimulants based on seaweed extracts, protein hydrolysate, and chitosan were found able to improve strawberry commercial (firmness and external color) and nutritional (phenolic compounds) quality. The outcomes of this research allow therefore a positive overall evaluation of biostimulants as agronomic tools able to contrast the negative consequence of growing crops under insufficient nutritional conditions. Further work needs to be done to deepen our understanding of the uptake mechanisms and use efficacy of the biostimulants under the current strawberry industrial production systems, according to their way of application and interaction with the different farming techniques (open field or protected cultivations, fresh or cold stored plants, genotypes, etc.).

Supplementary Materials: The following are available online at http://www.mdpi.com/2073-4395/9/9/483/s1, Figure S1. Cold stored strawberry plants before transplantation (0 DAT). Figure S2. Strawberry plants at the end of the experiment (90 DAT) as affected by the application of the different biostimulants. Treatments legend: CON, control; HAL, humic acids; APH, alfalfa protein hydrolysate; SEA, macroseaweed extract; SPI, microalga hydrolysate; MAA, mix of amino acids; PHE, MAA combined with pure phenylalanine; ZIN, MAA combined with zinc; VIT, B-group vitamins; CHI, chitosan; SIL, Siliforce ${ }^{\circledR}$.

Author Contributions: S.S. contributed in the set-up of the experimental protocol, performed the experiment, processed the fruit samples, analyzed the data, and participated in the writing of the paper; M.K. contributed to the set-up of the experiment and to the interpretation of the results; C.C. gave technical assistance for the implementation of the study; M.B. contributed to the analysis of phenols, anthocyanins, antioxidant potential, and ascorbic acid; P.R. contributed to the set-up of the analytical work related to the quality indices of the fruits; A.M. contributed to the analysis of mineral elements; C.A. coordinated the research, worked on the statistical analysis, and contributed to the writing of several sections of the manuscript.

Funding: The research was co-founded by the Free University of Bozen-Bolzano (Project BIO_TOOL TN 1B07), Laimburg Research Centre, and ILSA S.p.A. Laimburg Research Centre was funded by the Autonomous Province of Bolzano; financial support for the "Technology Park" (Decision no. 1472, 07.10.2013) is gratefully acknowledged. This work was also supported by the Open Access Publishing Fund of the Free University of Bozen-Bolzano. SS was funded by a Ph.D. grant from the Free University of Bozen-Bolzano.

Conflicts of Interest: ILSA S.p.A. provided part of the biostimulants used for the experiment. The design of the study, the collection, the analysis and interpretation of the data, as well as article writing of the manuscript was 
carried out by the authors independently. The authors declare that the research was conducted in the absence of any commercial or financial relationships that could be construed as a potential conflict of interest.

\section{References}

1. Tagliavini, M.; Baldi, E.; Lucchi, P.; Antonelli, M.; Sorrenti, G.; Baruzzi, G.; Faedi, W. Dynamics of nutrients uptake by strawberry plants (Fragaria $\times$ ananassa Dutch.) grown in soil and soilless culture. Eur. J. Agron. 2005, 23, 15-25. [CrossRef]

2. Albregts, E.E.; Howard, C.M.; Chandler, C.K. Strawberry responses to K rate on a fine sand soil. Hort. Sci. 1991, 26, 135-138. [CrossRef]

3. Shirko, R.; Nazarideljou, M.J.; Akbar, M.A.; Naser, G. Photosynthetic reaction, mineral uptake, and fruit quality of strawberry affected by different levels of macronutrients. J. Plant Nutr. 2018, 41, 1807-1820. [CrossRef]

4. Hukkanen, A.T.; Kokko, H.I.; Buchala, A.J.; McDougall, G.J.; Stewart, D.; Kärenlampi, S.O.; Karjalainen, R.O. Benzothiadiazole induces the accumulation of phenolics and improves resistance to powdery mildew in strawberries. J. Agric. Food Chem. 2007, 55, 1862-1870. [CrossRef] [PubMed]

5. de Ponti, T.; Rijk, B.; van Ittersum, M.K. The crop yield gap between organic and conventional agriculture. Agric. Syst. 2012, 108, 1-9. [CrossRef]

6. van Eysinga, J.R.; van Caem, H.E. Nutrition of glasshouse strawberries with nitrogen, phosphorus and potassium. Sci. Hortic. 1977, 7, 359-368. [CrossRef]

7. European Council. Available online: https://www.consilium.europa.eu/ (accessed on 11 May 2019).

8. Goñi, O.; Quille, P.; O'Connell, S. Ascophyllum nodosum extract biostimulants and their role in enhancing tolerance to drought stress in tomato plants. Plant Physiol. Biochem. 2018, 126, 63-73. [CrossRef]

9. Di Stasio, E.; Van Oosten, M.J.; Silletti, S.; Raimondi, G.; dell'Aversana, E.; Carillo, P.; Maggio, A. Ascophyllum nodosum-based algal extracts act as enhancers of growth, fruit quality, and adaptation to stress in salinized tomato plants. J. Appl. Phycol. 2018, 30, 2675-2686. [CrossRef]

10. Lucini, L.; Rouphael, Y.; Cardarelli, M.; Canaguier, R.; Kumar, P.; Colla, G. The effect of a plant-derived biostimulant on metabolic profiling and crop performance of lettuce grown under saline conditions. Sci. Hortic. 2015, 182, 124-133. [CrossRef]

11. Li, Z.; Zhang, Y.; Zhang, X.; Merewitz, E.; Peng, Y.; Ma, X.; Huang, L.; Yan, Y. Metabolic pathways regulated by chitosan contributing to drought resistance in white clover. J. Proteome Res. 2017, 16, 3039-3052. [CrossRef]

12. Shi, Y.; Zhang, Y.; Han, W.; Feng, R.; Hu, Y.; Guo, J.; Gong, H. Silicon enhances water stress tolerance by improving root hydraulic conductance in Solanum lycopersicum L. Front. Plant Sci. 2016, 7, 196. [CrossRef]

13. De Pascale, S.; Rouphael, Y.; Colla, G. Plant biostimulants: Innovative tool for enhancing plant nutrition in organic farming. Eur. J. Hortic. Sci. 2018, 82, 277-285. [CrossRef]

14. Halpern, M.; Bar-Tal, A.; Ofek, M.; Minz, D.; Muller, T.; Yermiyahu, U. The use of biostimulants for enhancing nutrient uptake. In Advances in Agronomy; Sparks, D.L., Ed.; Elsevier Science Publishing Co Inc.: San Diego, CA, USA, 2015; Volume 130, pp. 141-174. ISBN 978-0-12-802137-8.

15. Mattner, S.W.; Milinkovic, M.; Arioli, T. Increased growth response of strawberry roots to a commercial extract from Durvillaea potatorum and Ascophyllum nodosum. J. Appl. Phycol. 2018, 30, 2943-2951. [CrossRef]

16. Crouch, I.J.; Beckett, R.P.; Van Staden, J. Effect of seaweed concentrate on the growth and mineral nutrition of nutrient-stressed lettuce. J. Appl. Phycol. 1990, 2, 269-272. [CrossRef]

17. Rathore, S.S.; Chaudhary, D.R.; Boricha, G.N.; Ghosh, A.; Bhatt, B.P.; Zodape, S.T.; Patolia, J.S. Effect of seaweed extract on the growth, yield and nutrient uptake of soybean (Glycine max) under rainfed conditions. South Afr. J. Bot. 2009, 75, 351-355. [CrossRef]

18. Rouphael, Y.; De Micco, V.; Arena, C.; Raimondi, G.; Colla, G.; De Pascale, S. Effect of Ecklonia maxima seaweed extract on yield, mineral composition, gas exchange, and leaf anatomy of zucchini squash grown under saline conditions. J. Appl. Phycol. 2017, 29, 459-470. [CrossRef]

19. Spinelli, F.; Fiori, G.; Noferini, M.; Sprocatti, M.; Costa, G. A novel type of seaweed extract as a natural alternative to the use of iron chelates in strawberry production. Sci. Hortic. 2010, 125, 263-269. [CrossRef]

20. Ghasemi, S.; Khoshgoftarmanesh, A.H.; Afyuni, M.; Hadadzadeh, H. Iron(II)-amino acid chelates alleviate salt-stress induced oxidative damages on tomato grown in nutrient solution culture. Sci. Hortic. 2014, 165, 91-98. [CrossRef] 
21. Soppelsa, S.; Kelderer, M.; Casera, C.; Bassi, M.; Robatscher, P.; Andreotti, C. Use of biostimulants for organic apple production: Effects on tree growth, yield, and fruit quality at harvest and during storage. Front. Plant Sci. 2018, 9, 1342. [CrossRef]

22. Colla, G.; Cardarelli, M.; Bonini, P.; Rouphael, Y. Foliar applications of protein hydrolysate, plant and seaweed extracts increase yield but differentially modulate fruit quality of greenhouse tomato. Hortscience 2017, 52, 1214-1220. [CrossRef]

23. Mohamed, A.Y.; El-Sehrawy, O.A. Effect of seaweed extract on fruiting of Hindy Bisinnara mango trees. J. Am. Sci. 2013, 9, 537-544.

24. El-Miniawy, S.; Ragab, M.; Youssef, S.; Metwally, A. Response of strawberry plants to foliar spraying of chitosan. Res. J. Agric. Biol. Sci. 2013, 9, 366-372.

25. Neri, D.; Lodolini, E.M.; Savini, G.; Sabbatini, P.; Bonanomi, G.; Zucconi, F. Foliar application of humic acids on strawberry (cv Onda). In Proceedings of the Acta Horticulturae; International Society for Horticultural Science (ISHS): Leuven, Belgium, November 2002; pp. 297-302.

26. Roussos, P.A.; Denaxa, N.-K.; Damvakaris, T. Strawberry fruit quality attributes after application of plant growth stimulating compounds. Sci. Hortic. 2009, 119, 138-146. [CrossRef]

27. Fan, D.; Hodges, D.M.; Zhang, J.; Kirby, C.W.; Ji, X.; Locke, S.J.; Critchley, A.T.; Prithiviraj, B. Commercial extract of the brown seaweed Ascophyllum nodosum enhances phenolic antioxidant content of spinach (Spinacia oleracea L.) which protects Caenorhabditis elegans against oxidative and thermal stress. Food Chem. 2011, 124, 195-202. [CrossRef]

28. Rouphael, Y.; Giordano, M.; Cardarelli, M.; Cozzolino, E.; Mori, M.; Kyriacou, M.; Bonini, P.; Colla, G. Plant-and seaweed-based extracts increase yield but differentially modulate nutritional quality of greenhouse spinach through biostimulant action. Agronomy 2018, 8, 126. [CrossRef]

29. Cai, Z.; Kastell, A.; Mewis, I.; Knorr, D.; Smetanska, I. Polysaccharide elicitors enhance anthocyanin and phenolic acid accumulation in cell suspension cultures of Vitis vinifera. Plant Cell Tissue Organ Cult. Pctoc 2012, 108, 401-409. [CrossRef]

30. Portu, J.; López-Alfaro, I.; Gómez-Alonso, S.; López, R.; Garde-Cerdán, T. Changes on grape phenolic composition induced by grapevine foliar applications of phenylalanine and urea. Food Chem. 2015, 180, 171-180. [CrossRef]

31. El-Sayed, M.E.A. Improving fruit quality and marketing of "Crimson Seedless" grape using some preharvest treatments. J. Hortic. Sci. Ornam. Plants 2013, 5, 218-226.

32. Ertani, A.; Schiavon, M.; Muscolo, A.; Nardi, S. Alfalfa plant-derived biostimulant stimulate short-term growth of salt stressed Zea mays L. plants. Plant Soil 2012, 364, 145-158. [CrossRef]

33. Landi, L.; Feliziani, E.; Romanazzi, G. Expression of defense genes in strawberry fruits treated with different resistance inducers. J. Agric. Food Chem. 2014, 62, 3047-3056. [CrossRef]

34. Schiavon, M.; Pizzeghello, D.; Muscolo, A.; Vaccaro, S.; Francioso, O.; Nardi, S. High Molecular Size Humic Substances Enhance Phenylpropanoid Metabolism in Maize (Zea mays L.). J. Chem. Ecol. 2010, 36, 662-669. [CrossRef]

35. Vera, J.; Castro, J.; Gonzalez, A.; Moenne, A. Seaweed polysaccharides and derived oligosaccharides stimulate defense responses and protection against pathogens in plants. Mar. Drugs 2011, 9, 2514-2525. [CrossRef]

36. Xie, L.; Wang, Z.H.; Cheng, X.H.; Gao, J.J.; Zhang, Z.P.; Wang, L.J. 5-Aminolevulinic acid promotes anthocyanin accumulation in Fuji apples. Plant Growth Regul. 2013, 69, 295-303. [CrossRef]

37. Youssef, K.; Sanzani, S.M.; Ligorio, A.; Ippolito, A.; Terry, L.A. Sodium carbonate and bicarbonate treatments induce resistance to postharvest green mould on citrus fruit. Postharvest Biol. Technol. 2014, 87, 61-69. [CrossRef]

38. Saa, S.; Olivos-Del Rio, A.; Castro, S.; Brown, P.H. Foliar application of microbial and plant based biostimulants increases growth and potassium uptake in almond (Prunus dulcis [Mill.] D. A. Webb). Front. Plant Sci 2015, 6. [CrossRef]

39. Rouphael, Y.; Colla, G. Synergistic biostimulatory action: Designing the next generation of plant biostimulants for sustainable agriculture. Front. Plant Sci. 2018, 9, 1655. [CrossRef]

40. Sacks, E.J.; Shaw, D.V. Color change in fresh strawberry fruit of seven genotypes stored at 0C. HortScience 1993, 28, 209-210. [CrossRef]

41. Meyers, K.J.; Watkins, C.B.; Pritts, M.P.; Liu, R.H. Antioxidant and antiproliferative activities of strawberries. J. Agric. Food Chem. 2003, 51, 6887-6892. [CrossRef] 
42. Lee, J.; Durst, R.W.; Wrolstad, R.E. Determination of total monomeric anthocyanin pigment content of fruit juices, beverages, natural colorants, and wines by the $\mathrm{pH}$ differential method: Collaborative study. J. Aoac Int. 2005, 88, 1269-1278.

43. Re, R.; Pellegrini, N.; Proteggente, A.; Pannala, A.; Yang, M.; Rice-Evans, C. Antioxidant activity applying an improved ABTS radical cation decolorization assay. Free Radic. Biol. Med. 1999, 26, 1231-1237. [CrossRef]

44. Bassi, M.; Lubes, G.; Bianchi, F.; Agnolet, S.; Ciesa, F.; Brunner, K.; Guerra, W.; Robatscher, P.; Oberhuber, M. Ascorbic acid content in apple pulp, peel, and monovarietal cloudy juices of 64 different cultivars. Int. J. Food Prop. 2018, 1-9. [CrossRef]

45. AOAC Vitamin C in juices and vitamin preparations. Official Method 967.21; AOAC Official Methods of Analysis, 18th; Association of Official Analytical Chemists: Gaithersburg, MD, USA, 2005; p. 45.1.14.

46. ISO 16634-1:2008. Food Products-Determination of the Total Nitrogen Content by Combustion According to the Dumas Principle and Calculation of the Crude Protein Content_Part 1: Oilseeds and Animal Feeding Stuffs; International Organization for Standardization: Geneva, Switzerland, 2008.

47. EPA 3052. Microwave assisted acid digestion of siliceous and organically based matrics; U.S. Environmental Protection Agency: Washington, DC, USA, 1996.

48. EPA 6010D. Inductively coupled plasma-Optical emission spectrometry; U.S. Environmental Protection Agency: Washington, DC, USA, 2018.

49. Dunnett, C.W. Multiple comparisons between several treatments and a specified treatment. In Proceedings of the Linear Statistical Inference; Caliński, T., Klonecki, W., Eds.; Springer: New York, NY, USA, 1985; pp. $39-47$.

50. Cramer, G.R.; Urano, K.; Delrot, S.; Pezzotti, M.; Shinozaki, K. Effects of abiotic stress on plants: A systems biology perspective. Bmc Plant Biol. 2011, 11, 163. [CrossRef]

51. Jarosz, Z.; Konopinska, J. Effect of substrate type and nitrogen fertilization upon yielding and chemical composition of 'Elsanta' strawberry cultivar grown in unheated foil tunnel. Acta Sci. Pol. Hortorum Cultus 2010, 9, 87-96.

52. Saied, A.S.; Keutgen, A.J.; Noga, G. The influence of $\mathrm{NaCl}$ salinity on growth, yield and fruit quality of strawberry cvs. 'Elsanta' and 'Korona'. Sci. Hortic. 2005, 103, 289-303. [CrossRef]

53. Casierra-Posada, F.; Torres, I.D.; Blanke, M.M. Fruit quality and yield in partially defoliated strawberry plants in the tropical highlands. Gesunde Pflanz. 2013, 65, 107-112. [CrossRef]

54. Almaliotis, D.; Velemis, D.; Bladenopoulou, S.; Karapetsas, N. Leaf nutrient levels of strawberries (cv Tudla) in relation to crop yield. In Proceedings of the Acta Horticulturae; International Society for Horticultural Science (ISHS): Leuven, Belgium, 2002; pp. 447-450.

55. Campbell, C.R.; Miner, G.S. Strawberry, annual hill culture. In Reference sufficiency ranges for plant analysis in the southern region of the United States; Southern Cooperative Series Bulletin 394; North Carolina Department of Agriculture \& Consumer Services: Raleigh, NC, USA, 2000; ISBN 1-58161-394-6.

56. Jamali, B.; Eshghi, S.; Tafazoli, E. Mineral composition of 'Selva' strawberry as affected by time of application of nitric oxide under saline conditions. Hortic. Env. Biotechnol. 2015, 56, 273-279. [CrossRef]

57. Popko, M.; Michalak, I.; Wilk, R.; Gramza, M.; Chojnacka, K.; Górecki, H. Effect of the new plant growth biostimulants based on amino acids on yield and grain quality of winter wheat. Molecules 2018, $23,470$. [CrossRef]

58. Kaya, C.; Tuna, A.L.; Guneri, M.; Ashraf, M. Mitigation effects of silicon on tomato plants bearing fruit grown at high boron levels. J. Plant Nutr. 2011, 34, 1985-1994. [CrossRef]

59. Tsadilas, C.D.; Kassioti, T.; Mitsios, I.K. Influence of liming and nitrogen forms on boron uptake by tobacco. Commun. Soil Sci. Plant Anal. 2005, 36, 701-708. [CrossRef]

60. Hellequin, E.; Monard, C.; Quaiser, A.; Henriot, M.; Klarzynski, O.; Binet, F. Specific recruitment of soil bacteria and fungi decomposers following a biostimulant application increased crop residues mineralization. PLoS ONE 2019, 13, e0209089. [CrossRef]

61. Ertani, A.; Sambo, P.; Nicoletto, C.; Santagata, S.; Schiavon, M.; Nardi, S. The use of organic biostimulants in hot pepper plants to help low input sustainable agriculture. Chem. Biol. Technol. Agric. 2015, 2, 11. [CrossRef]

62. Rouphael, Y.; Colla, G.; Giordano, M.; El-Nakhel, C.; Kyriacou, M.C.; De Pascale, S. Foliar applications of a legume-derived protein hydrolysate elicit dose-dependent increases of growth, leaf mineral composition, yield and fruit quality in two greenhouse tomato cultivars. Sci. Hortic. 2017, 226, 353-360. [CrossRef] 
63. Colla, G.; Hoagland, L.; Ruzzi, M.; Cardarelli, M.; Bonini, P.; Canaguier, R. Biostimulant action of protein hydrolysates: Unraveling their effects on plant physiology and microbiome. Front. Plant Sci. 2017, 8, 2202. [CrossRef]

64. Goyer, A. Thiamine in plants: Aspects of its metabolism and functions. Phytochemistry 2010, 71, 1615-1624. [CrossRef]

65. Rapala-Kozik, M. Vitamin B1 (thiamine): A cofactor for enzymes involved in the main metabolic pathways and an environmental stress protectant. In Advances in Botanical Research; Rébeillé, F., Douce, R., Eds.; Academic Press: Cambridge, MA, USA, 2011; Volume 58, pp. 37-91. ISBN 0065-2296.

66. Mukta, J.; Rahman, M.; As Sabir, A.; Gupta, D.R.; Surovy, M.Z.; Rahman, M.; Islam, M.T. Chitosan and plant probiotics application enhance growth and yield of strawberry. Biocatal. Agric. Biotechnol. 2017, 11, 9-18. [CrossRef]

67. Hajiboland, R.; Moradtalab, N.; Eshaghi, Z.; Feizy, J. Effect of silicon supplementation on growth and metabolism of strawberry plants at three developmental stages. N. Z. J. Crop Hortic. Sci. 2018, 46, 144-161. [CrossRef]

68. Agostinho, F.; Tubana, B.; Martins, M.; Datnoff, L. Effect of different silicon sources on yield and silicon uptake of rice grown under varying phosphorus rates. Plants 2017, 6, 35. [CrossRef]

69. Artyszak, A. Effect of silicon fertilization on Crop yield quantity and quality: A literature review in Europe. Plants 2018, 7, 54. [CrossRef]

70. DiMario, R.J.; Clayton, H.; Mukherjee, A.; Ludwig, M.; Moroney, J.V. Plant carbonic anhydrases: Structures, locations, evolution, and physiological roles. Mol. Plant 2017, 10, 30-46. [CrossRef]

71. Sturikova, H.; Krystofova, O.; Huska, D.; Adam, V. Zinc, zinc nanoparticles and plants. J. Hazard. Mater. 2018, 349, 101-110. [CrossRef]

72. Mattiello, E.M.; Ruiz, H.A.; Neves, J.C.L.; Ventrella, M.C.; Araújo, W.L. Zinc deficiency affects physiological and anatomical characteristics in maize leaves. J. Plant Physiol. 2015, 183, 138-143. [CrossRef]

73. Kyriacou, M.C.; Rouphael, Y. Towards a new definition of quality for fresh fruits and vegetables. Sci. Hortic. 2018, 234, 463-469. [CrossRef]

74. Rouphael, Y.; Kyriacou, M.C.; Petropoulos, S.A.; De Pascale, S.; Colla, G. Improving vegetable quality in controlled environments. Sci. Hortic. 2018, 234, 275-289. [CrossRef]

75. Bhaskara Reddy, M.; Belkacemi, K.; Corcuff, R.; Castaigne, F.; Arul, J. Effect of pre-harvest chitosan sprays on post-harvest infection by Botrytis cinerea and quality of strawberry fruit. Postharvest Biol. Technol. 2000, 20, 39-51. [CrossRef]

76. Hernández-Muñoz, P.; Almenar, E.; Valle, V.D.; Velez, D.; Gavara, R. Effect of chitosan coating combined with postharvest calcium treatment on strawberry (Fragaria $\times$ ananassa) quality during refrigerated storage. Food Chem. 2008, 110, 428-435. [CrossRef]

77. Khan, A.S.; Ahmad, B.; Jaskani, M.J.; Ahmad, R.; Malik, A.U. Foliar application of mixture of amino acids and seaweed (Ascophyllum nodosum) extract improve growth and physicochemical properties of grapes. Int. J. Agric. Biol. 2012, 14, 383-388.

78. Cluzet, S.; Torregrosa, C.; Jacquet, C.; Lafitte, C.; Fournier, J.; Mercier, L.; Salamagne, S.; Briand, X.; Esquerre'-Tugaye', M.-T.; Dumas, B. Gene expression profiling and protection of Medicago truncatula against a fungal infection in response to an elicitor from green algae Ulva spp. Plant Cell Env. 2004, 27, 917-928. [CrossRef]

79. Ertani, A.; Pizzeghello, D.; Francioso, O.; Sambo, P.; Sanchez-Cortes, S.; Nardi, S. Capsicum chinensis L. growth and nutraceutical properties are enhanced by biostimulants in a long-term period: Chemical and metabolomic approaches. Front. Plant. Sci. 2014, 5. [CrossRef]

80. Olkhovych, O.; Volkogon, M.; Taran, N.; Batsmanova, L.; Kravchenko, I. The Effect of copper and zinc nanoparticles on the growth parameters, contents of ascorbic acid, and qualitative composition of amino acids and acylcarnitines in Pistia stratiotes L. (Araceae). Nanoscale Res. Lett. 2016, 11. [CrossRef]

(C) 2019 by the authors. Licensee MDPI, Basel, Switzerland. This article is an open access article distributed under the terms and conditions of the Creative Commons Attribution (CC BY) license (http://creativecommons.org/licenses/by/4.0/). 